\title{
Highly Efficient Synthesis of (Phosphinodihydrooxazole)- (1,5-cyclooctadiene) Iridium Complexes
}

\author{
Volodymyr Semeniuchenko ${ }^{\mathrm{a}, \mathrm{b}}$, Volodymyr Khilya ${ }^{\mathrm{b}}$, and Ulrich Groth ${ }^{\mathrm{a}}$ \\ ${ }^{a}$ Fachbereich Chemie und Konstanz Research School Chemical Biology, Universität Konstanz, \\ 78457 Konstanz, Germany \\ b Department of Chemistry, National Taras Shevchenko University, Kyiv, Ukraine \\ Reprint requests to Dr. Volodymyr Semeniuchenko. Fax: +497531884155. \\ E-mail: chem_vova@mail.univ.kiev.ua
}

Z. Naturforsch. 2009, 64b, 1147 -1158; received June 7, 2009

\begin{abstract}
A highly efficient one-pot procedure for the synthesis of complexes of the type $[\operatorname{Ir}(\mathrm{COD})(\mathrm{Phox})] \mathrm{X}$, where Phox is a (chiral) phosphinooxazoline ligand, $\mathrm{X}=\mathrm{PF}_{6}$ or $\mathrm{B}\left[\left(3,5-\left(\mathrm{CF}_{3}\right)_{2} \mathrm{C}_{6} \mathrm{H}_{3}\right)\right]_{4}(\mathrm{BARF})$, is developed. Former reported syntheses demanded the isolation of pure ligands by column chromatography, but the ligands tend to adsorb irreversibly on silica. Moreover, the chromatography has to be performed with careful exclusion of air. The present method avoids this difficulties. The yields of the syntheses are comparable with those starting from the pure ligands. The method is also suitable for the preparation of complexes of the type $[\mathrm{Rh}(\mathrm{COD})(\mathrm{Phox})] \mathrm{BARF}$ and $\left[\mathrm{Rh}(\mathrm{Phox})_{2}\right] \mathrm{BARF}$.
\end{abstract}

Key words: Iridium, Rhodium, Chiral Ligand, Homogeneous Catalysis, Heterocycles

\section{Introduction}

Chiral phosphinodihydrooxazole complexes of iridium are valuable catalysts which are used in homogeneous enantioselective hydrogenation. In a pioneering work of A. Lightfoot, P. Schnider and A. Pfaltz, complexes of type 4 (see Scheme 2) were shown to catalyze enantiospecific hydrogenation of stilbenes and styrenes [1]. Imines were also hydrogenated with high enantioselectivity [2]. Enantioselective hydrogenation, catalyzed by these complexes, could also be carried out in supercritical $\mathrm{CO}_{2}[3,4]$. Recently, we have found a new reaction for the homogeneous hydrogenation of electron-deficient alkenes, catalyzed by complexes of the type $\left[\operatorname{Ir}(\mathrm{COD})\left(\mathrm{P}^{\wedge} \mathrm{N}\right)\right] \mathrm{BARF}(\mathrm{COD}$ stands for 1,5-cyclooctadiene, BARF for tetrakis(3,5bis(trifluoromethyl)phenyl)borate, $\mathrm{P}^{\wedge} \mathrm{N}$ for a $\kappa^{2}-P, N$ coordinated ligand) in the presence of ethyldiisopropylamine [5].

Current methods for the syntheses of these complexes comprise the syntheses of the ligands, their isolation and purification (via column chromatography), followed by complexation on iridium (Scheme 1).

According to the push-pull phosphinylation mechanism [6], method 1 [7] requires an excess of phosphine, which prevents crystallization of the ligand, which thus must be separated by column chromatography. In our hands, method 1 was reproducible up to chromatogra-

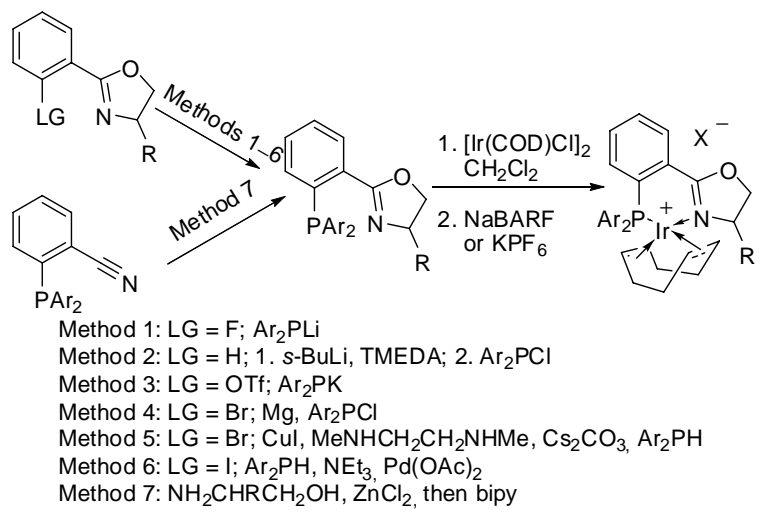

Scheme 1. Methods for the synthesis of phox ligands and the corresponding iridium complexes.

phy. Ligand 3c (Scheme 2) has been described as an air-stable compound [8], but in our experiments this was not the case. The chromatography must be performed strictly under nitrogen on deoxygenated sorbens using deoxygenated eluent, otherwise the phosphine oxide derived from $3 \mathbf{c}$ is detected by ${ }^{31} \mathrm{P}$ NMR. The main problem was the irreversible adsorption of the ligand on silica, neutral or basic alumina, such that it remained in the column even when triethylamine was added to the eluent. The irreversible adsorption lowered the yield of the ligand to $20-30 \%$. Method 2 [9] gave the desired phosphinooxazolines with a best GC 


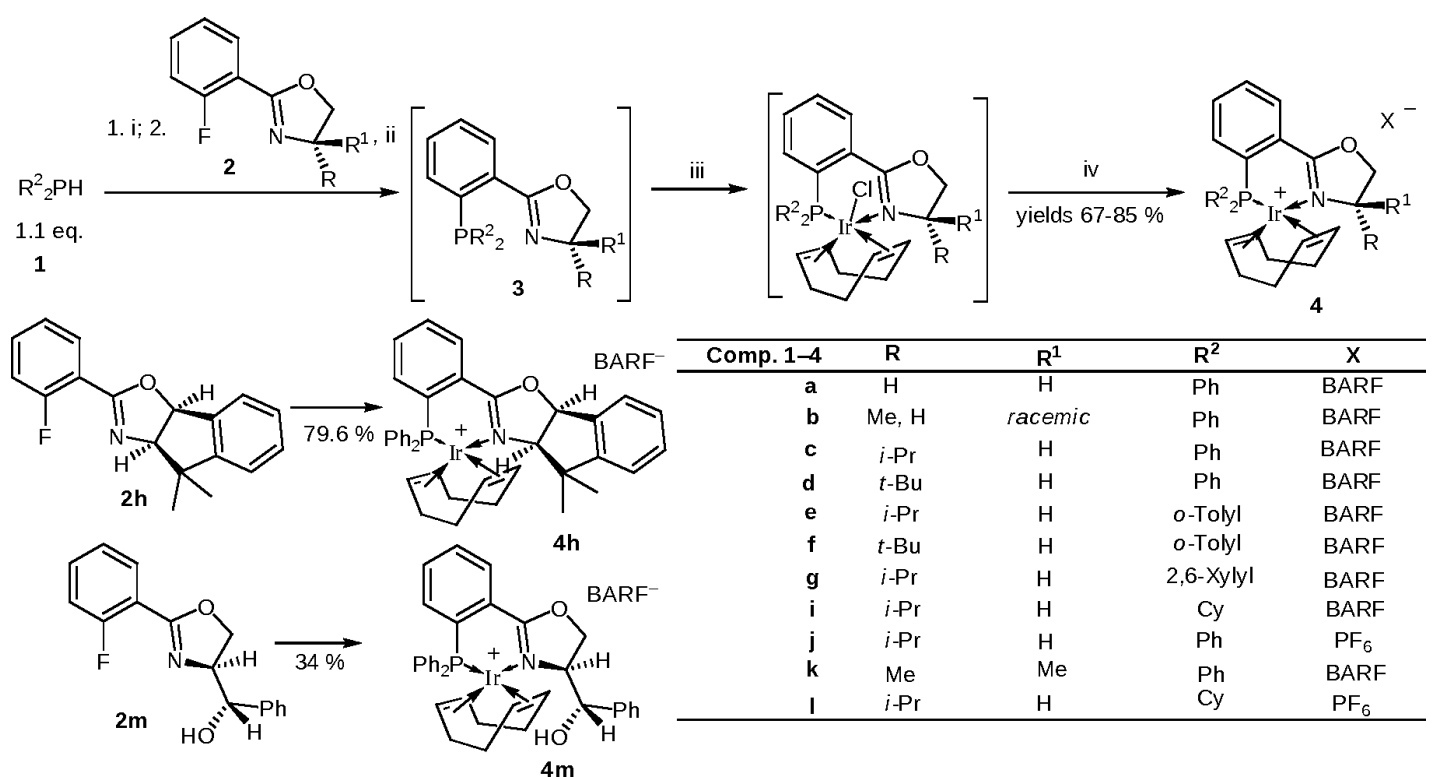

Scheme 2. One-pot synthesis of complexes of the type $[\operatorname{Ir}(\mathrm{COD})(\mathrm{Phox})] \mathrm{X}$. Reagents and conditions: i: 1.1 eq. $n \mathrm{BuLi}, \mathrm{Et}_{2} \mathrm{O}$, 5 min or MTBE, 30 min (for 1g, 1i), r.t.; ii: 1 eq., stiring in $\mathrm{Et}_{2} \mathrm{O}$ at r.t. or reflux in MTBE, $10 \mathrm{~h}(\mathbf{2})$; iii: $[\operatorname{Ir}(\mathrm{COD}) \mathrm{Cl}]_{2}$, $\mathrm{CH}_{2} \mathrm{Cl}_{2}, 2-4 \mathrm{~h}$, reflux; iv: $\mathrm{NaBARF}$ or $\mathrm{KPF}_{6}, \mathrm{CH}_{2} \mathrm{Cl}_{2}, 1-4 \mathrm{~h}$.

yield of $20 \%$, and hence was not further explored. According to ref. [10], method 3 gives impure ligand, and hence chromatography is necessary. Methods 4 [7], 5 [11], $6[12]$ and $7[13,14]$ also require column chromatography.

\section{Results and Discussion}

In order to obtain the required complexes we developed the following one-pot procedure (Scheme 2). The preparation of the ligand has also been simplified compared to that in ref. [7]. Although the possibility of complexation of impure ligand was indicated in the literature, the particular procedure was either not described [15], or the crude ligand was only filtered through a plug of silica gel [16].

Chiral 2-(2-fluorophenyl)-4- $R$-4,5-dihydrooxazoles 2 are normally synthesized from aminoalcohols, the latter being derivatives of natural and synthetic chiral amino acids (except $\mathbf{2 h}$ ). Although it would be possible to synthesize the complex $\mathbf{2 b}$ in enantiomerically pure form from chiral alaninol, for our purposes (the above mentioned DIPEA-activated Ir-catalyzed hydrogenation) we needed only a racemic complex.

Compounds $\mathbf{4}$ are insensitive to oxygen and moisture and could be purified by column chromatography (preferably those with BARF as anion) or precipita- tion by ether (those with the $\mathrm{PF}_{6}{ }^{-}$anion). The complexes are colored which makes monitoring of the column chromatography extremely simple, because there is no need of fraction collecting.

The identity of the synthesized complexes was confirmed by ${ }^{1} \mathrm{H},{ }^{13} \mathrm{C}$ and ${ }^{31} \mathrm{P}$ NMR spectra and by HRMS ESI/FT-ICR. Compounds 4c [1, 15], $\mathbf{4 f}$ [1, 15], 4i [15] and $4 \mathbf{1}$ [15] are described in the literature, but the NMR spectra for $\mathbf{4 i}$ and $\mathbf{4 l}$ have not been reported.

$n$-Butyllithium was used to deprotonate the diarylor dialkylphosphines. Although according to ref. [17] the use of $s-\mathrm{BuLi}$ is preferred, it does not result in a better yield of complex 4 . The use of THF is avoided in the ligand preparation (except $\mathbf{4 m}$ ). THF is known to slowly react with lithium diphenylphosphide [18-20], thus decreasing the yield of the desired ligand. Sterically unhindered diphenylphosphine and hindered di-o-tolyl-, dixylyl- and dicyclohexylphosphine readily enter in the phosphinylation reaction, giving the corresponding ligands and complexes, but hindered phosphines must be deprotonated during $30 \mathrm{~min}$ in MTBE, and then refluxed overnight with fluoroxazoline 2c (otherwise the conversion of $\mathbf{2 c}$ is incomplete). Lithium ditert-butylphosphide, bis(trimethylsilyl)phosphide and phospholan-1-ide failed to enter in this reaction, i.e. ligand formation was not detected. 


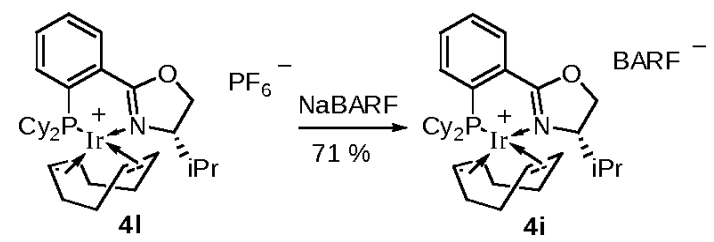

Scheme 3. Synthesis of pure $\mathbf{4 i}$.

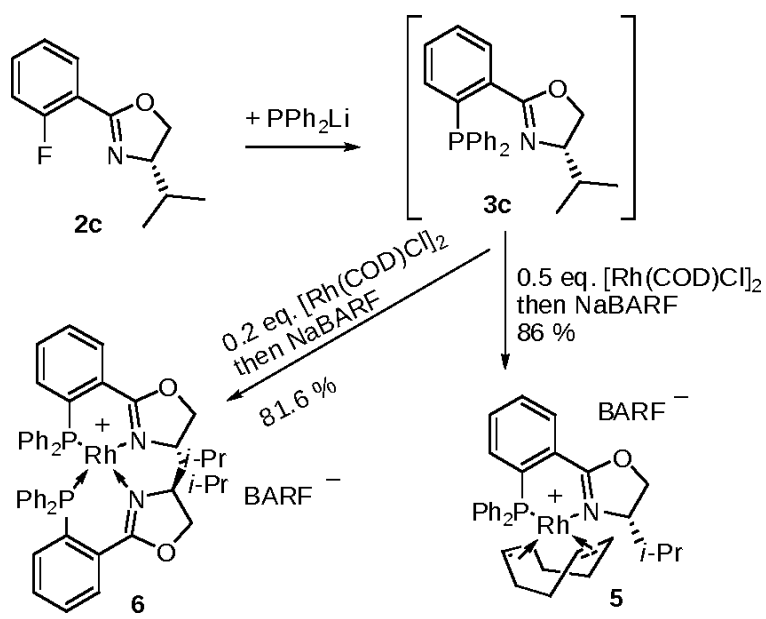

Scheme 4. Preparation of the Rh complexes 5 and $\mathbf{6}$.

Complex 4i and dicyclohexylphosphine oxide are coeluted by dichloromethane and could not be separated even by hexane-dichloromethane gradient chromatography. The analytically pure complex $4 \mathbf{i}$ was synthesized from $4 \mathbf{l}$ (Scheme 3). The latter was purified by precipitation with ether from a dichloromethane solution.

Complex $\mathbf{4 g}$ was obtained in impure form. All attempts to purify it by gradient chromatography (hexane-dichloromethane or hexane-chloroform) were unsuccessful. The complex with $\mathrm{PF}_{6}{ }^{-}$as counter-ion was also obtained in an impure state, and the abovementioned strategy with anion exchange was not applicable for $\mathbf{4 g}$. However, the formation of $\mathbf{4 g}$ was proven by its mass spectrum.

Being successful in the synthesis of the Ir complexes, we checked the possibility of synthesizing the analogous Rh complexes (Scheme 4). With 1 eq. of ligand for 1 eq. of Rh, complex 5 was synthesized. COD bound to $\mathrm{Rh}$ is more labile than that bound to Ir, therefore an excess of ligand yielded complex $\mathbf{6}$.

Because of the strong trans-effect of the phosphorus atom, the ligands in complex $\mathbf{6}$ are expected to be cisarranged. The iminic carbon gives rise to a triplet of doublets in the ${ }^{13} \mathrm{C}$ NMR spectrum, and this multiplic- ity is only possible for a cis-arrangement $\left({ }^{3} J_{\mathrm{CCCP}} \approx\right.$ $4.4 \mathrm{~Hz},{ }^{3} J_{\mathrm{CNRhP}} \approx 4.4 \mathrm{~Hz},{ }^{2} J_{\mathrm{CNRh}} \approx 1.5 \mathrm{~Hz}$ ). The fine structure was seen only on a $100 \mathrm{MHz}$ instrument (Varian ${ }^{\text {UNITY } I N O V A), ~ w h i l e ~ t h e ~}{ }^{13} \mathrm{C}$ NMR spectrum, acquired on a $150 \mathrm{MHz}$ (Bruker Avance DRX600) spectrometer, showed a broad singlet. The carbons $1-\mathrm{C}, 3^{\prime \prime}-\mathrm{CH}, 1^{\prime \prime}-\mathrm{C}$ and $2^{\prime \prime}-\mathrm{CH}$ (numbering is shown in Fig. 1, Experimental Section) of complex 6 give rise to pseudo-triplets in the ${ }^{13} \mathrm{C} N \mathrm{NMR}$ spectrum representing $\mathrm{AXX} Z \mathrm{Z}$ spin systems $\left(\mathrm{A}={ }^{13} \mathrm{C}, \mathrm{X}, \mathrm{X}^{\prime}={ }^{31} \mathrm{P}, \mathrm{Z}=\mathrm{Rh}\right)$.

Using this protocol, (4S)-2-(2-(diphenylarsino)phenyl)-4-isopropyl-4,5-dihydrooxazole (7) was synthesized from the oxazoline $2 \mathbf{c}$ and lithium diphenylarsinide. The complexes $[\operatorname{Ir}(\mathrm{COD})(7)] \mathrm{BARF}$ and $[\operatorname{Ir}(\mathrm{COD})(7)] \mathrm{PF}_{6}$ were found to be inherently unstable at r.t. and were detected only by mass spectrometry. The complex $[\operatorname{Ir}(\mathrm{COD})(7)]$ BARF was a weak hydrogenation catalyst of stilbene, that is why its research was discontinued.

The NMR spectra of complexes 4-6 are complicated because the signals in the proton spectra are not fully resolved (in both aromatic and aliphatic parts), and the chirality makes the atoms of phenyl rings and of COD magnetically nonequivalent. With the help of 2D techniques (HMBC, HSQC, COSY, TOCSY, ROESY and $J$-resolved) most assignments could be made. Not resolved multiplets (nrm) are inherent for the ${ }^{1} \mathrm{H}$ NMR spectra of these complexes. Although the shifts of individual peaks are indistinguishable in 1D spectra, the precise ${ }^{1} \mathrm{H}$ NMR shifts could be established from HSQC and HMBC experiments. 2D spectra were not measured for compounds $\mathbf{4 c}$ and $\mathbf{4 f}$, because their spectra are in agreement with the ones found in the literature.

Complex 4e has very interesting spectral properties. While the other compounds show a sharp ${ }^{31} \mathrm{P}$ NMR singlet, 4e shows two broad singlets at $\delta=+16.1$ and $+8.5 \mathrm{ppm}$ in $\mathrm{CDCl}_{3}$. The conformational stability known for tri-o-tolylphosphine [21] forced us to examine high-temperature ${ }^{31} \mathrm{P}$ NMR spectra of this compound. At $140{ }^{\circ} \mathrm{C}$ and higher temperatures the solution of $\mathbf{4 e}$ in 1,2,4-trichlorobenzene shows a sharp singlet at $\delta=+12.5 \mathrm{ppm}$ (line width $53.4 \mathrm{~Hz}$ ), whereas on cooling this singlet begins to broaden, and at $60{ }^{\circ} \mathrm{C}$ two broadened singlets appear. The approximate coalescence temperature in this solvent is $80{ }^{\circ} \mathrm{C}$. The ${ }^{1} \mathrm{H}$ NMR spectrum of this compound accordingly shows only broad lines. The complex reacts with DMSO when heated at $140{ }^{\circ} \mathrm{C}$. Therefore a resolved ${ }^{1} \mathrm{H}$ NMR spectrum of this compound which is in fast 
conformational equilibrium cannot be obtained. However, cooling to $-40{ }^{\circ} \mathrm{C}$ gave sharp peaks in the ${ }^{1} \mathrm{H},{ }^{13} \mathrm{C}$ and ${ }^{31} \mathrm{P}$ NMR spectra. Based on the relative integral intensity of the ${ }^{31} \mathrm{P}$ NMR signals (recorded without proton decoupling), the relative concentration of conformers at $-40{ }^{\circ} \mathrm{C}$ is $1: 0.75$ (at $\delta=+16.1$ and $+8.5 \mathrm{ppm}$, respectively). A full assignment of the NMR spectra of this complex cannot be achieved, since broad peaks in 1D NMR experiment result in low cross peaks in HSQC and HMBC spectra.

Further proof of the identity of complexes $4-6$ is provided by the mass spectra (with isotopic clusters) and the ability of the synthesized compounds to perform hydrogenation of stilbene under 100 bar of hydrogen in dichloromethane or toluene solution (except 6). As expected, the hydrogenation of stilbene in toluene was inhibited by ethyldiisopropylamine [15, 22, 23].

\section{Conclusion}

By using an easy synthetic procedure, complexes of the general formula $[\operatorname{Ir}(\mathrm{COD})(\mathrm{Phox})] \mathrm{BARF}$ and $[\operatorname{Ir}(\mathrm{COD})(\mathrm{Phox})] \mathrm{PF}_{6}$ were synthesized without isolation of the air-sensitive free ligands. By using this method two complexes of rhodium (5 and $\mathbf{6}$ ) were also synthesized. For compounds not fully characterized in the literature, full assignments of the NMR spectra were carried out. Complex $\mathbf{4 e}$ was found to exist as a mixture of two stable conformers at r.t.

\section{Experimental Section}

If not stated otherwise, solvents were dried and degassed by distillation over $\mathrm{Na} / \mathrm{K}$ alloy (or $\mathrm{CaH}_{2}$ for dichloromethane) in nitrogen atmosphere and stored under nitrogen. Diphenylphosphine was obtained from MCAT as a gift. $[\operatorname{Ir}(\mathrm{COD}) \mathrm{Cl}]_{2}$ was purchased from Chempur or obtained from Umicore as a gift. The other compounds were purchased from Sigma-Aldrich, Fluka, Acros, ABCR, and Fluorochem, or synthesized by known procedures: NaBARF [24], oxazolines [7]. GC/MS was performed on an HP GC/MS 5890/5972 instrument (EI, $70 \mathrm{eV}$ ) equipped with a Phenomenex Zebron ZB-5 column $(30 \mathrm{~m} \times 0.25 \mathrm{~mm} \times$ $0.25 \mu \mathrm{m})$. Helium was used as carrier gas. HRMS ESI/FTICR spectra were recorded on a Bruker APEX II FT/ICR instrument with a 7 Tesla magnet in positive polarization. Rotation angles were measured on a Perkin-Elmer 241 polarimeter with $5 \mathrm{sec}$ integration time. We used chloroform, stabilized with $1 \%$ of ethanol (Acros) for measurement of the rotation angles. NMR spectra were recorded on Bruker Avance DRX600 (600 MHz), Jeol JNM-LA 400 (400 MHz), or Varian UNITY INOVA 400 (400 MHz) instruments. Refer-

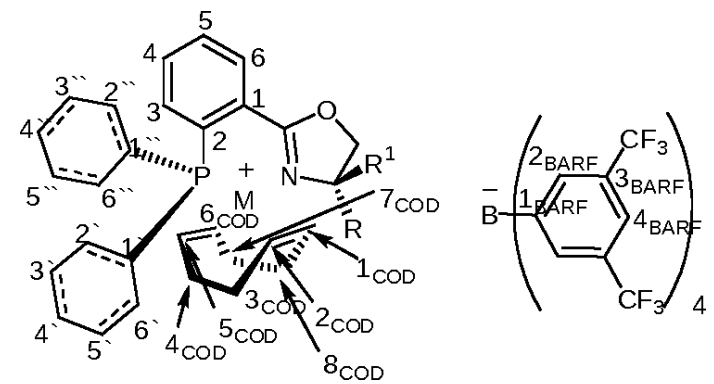

Fig. 1. Atom numbering for compounds 4-6, used for the assignment of NMR spectra.

ence standards are: TMS (internal) for ${ }^{1} \mathrm{H}$ and for ${ }^{31} \mathrm{C}$ NMR, $85 \% \mathrm{H}_{3} \mathrm{PO}_{4}$ (external) for ${ }^{31} \mathrm{P} \mathrm{NMR}, \mathrm{Et}_{2} \mathrm{O} \cdot \mathrm{BF}_{3}$ (external) for ${ }^{11} \mathrm{~B} \mathrm{NMR}, \mathrm{CFCl}_{3}$ (internal) for ${ }^{19} \mathrm{~F} \mathrm{NMR}$. "Nrm" stands for not resolved multiplet. In order to define the arrangement of ligands, the ${ }^{13} \mathrm{C}$ NMR spectrum of complex 6 was obtained using special parameters (spectral width $+175-$ $-5 \mathrm{ppm}, 256000$ points, acquisition time $7.0736 \mathrm{sec}$, relaxation delay $1 \mathrm{sec}$ ) on a UNITY INOVA 400 instrument. The numbering of atoms for compounds 4-6, used for assignment of the NMR spectra, is shown in Fig. 1 ( $2^{\prime}$ and $6^{\prime}$, $3^{\prime}$ and $5^{\prime}, 2^{\prime \prime}$ and $6^{\prime \prime}$ as well as $3^{\prime \prime}$ and $5^{\prime \prime}$ are inequivalent only for complexes $4 \mathrm{e}, \mathbf{4 g}$ and $4 \mathrm{~h}$ ).

All complexes bearing the BARF counter-ion, have shown the following signals in NMR spectra: ${ }^{1} \mathrm{H}$ NMR $\left(\mathrm{CDCl}_{3}\right.$, $600 \mathrm{MHz}$ ): $\delta=7.54$ (br s, $\left.4 \mathrm{H}, 4-\mathrm{H}_{\mathrm{BARF}}\right), 7.74$ (br s, $8 \mathrm{H}$, 2-H BARF $).-{ }^{13} \mathrm{C}\left\{{ }^{1} \mathrm{H}\right\}$ NMR $\left(\mathrm{CDCl}_{3}, 150 \mathrm{MHz}\right): \delta=117.50$ (br s, 4- $\mathrm{CH}_{\mathrm{BARF}}$ ), 124.55 (q, $J=273 \mathrm{~Hz}, \mathrm{CF}_{3}$ ), 128.9 (br $\left.\mathrm{q}, J=30 \mathrm{~Hz}, 3-\mathrm{C}_{\mathrm{BARF}}\right), 134.81$ (br s, 2-CH $\left.\mathrm{CH}_{\mathrm{BARF}}\right), 161.72$ (q $\left.1: 1: 1: 1, J=50.5 \mathrm{~Hz}, 1-\mathrm{C}_{\mathrm{BARF}}\right) .-{ }^{19} \mathrm{~F} \mathrm{NMR}\left(\mathrm{CDCl}_{3}\right.$, $376 \mathrm{MHz}): \delta=-62.8 .-{ }^{11} \mathrm{~B} \mathrm{NMR}\left(\mathrm{CDCl}_{3}, 128 \mathrm{MHz}\right)$ : $\delta=-6.9$.

CAUTION. All diarylphosphines, dialkylphosphines, lithium diaryl- and dialkyphosphides, and all ligands $\mathbf{3}$ are very toxic and pyrophoric compounds. All operations must be carried out strictly under inert gas in a well-ventilated fume hood or in a glovebox.

\section{Synthesis of bis(2,6-dimethylphenyl)phosphine oxide}

In $50 \mathrm{~mL}$ of absolute $\mathrm{Et}_{2} \mathrm{O}, 2$,6-dimethylbromobenzene (18.506 g, $0.1 \mathrm{~mol})$ and magnesium $(2.674 \mathrm{~g}, 0.11 \mathrm{~mol})$ were mixed in a nitrogen atmosphere. One crystal of iodine was added, and the mixture was heated by a heatgun. After the formation of the Grignard reagent had started, the mixture was refluxed for $3 \mathrm{~h}$ until the magnesium was dissolved. The mixture was cooled to $c a .-100{ }^{\circ} \mathrm{C}$ with liquid nitrogen, and diethyl phosphite $(3.8 \mathrm{~mL}, 0.03 \mathrm{~mol})$ was added. The mixture was warmed to r.t. and refluxed overnight $(c a .10 \mathrm{~h})$, cooled and poured into $200 \mathrm{~mL}$ of $1 \mathrm{~N}$ aqueous $\mathrm{HCl}$. The layers were separated, the aqueous phase washed with dichloromethane $(5 \times 100 \mathrm{~mL})$, the united organic phases were dried with 
$\mathrm{Na}_{2} \mathrm{SO}_{4}$, filtered, and evaporated. The residue was recrystallized from EtOAc to give white crystalline dixylylphosphine oxide $(4.768 \mathrm{~g}, 61 \%)$. The substance is moderately air-stable even in solution, but should be stored in the crystalline state in a nitrogen-filled glovebox. $-{ }^{1} \mathrm{H} \mathrm{NMR}\left(\mathrm{CDCl}_{3}, 400 \mathrm{MHz}\right)$ : $\delta=2.44(\mathrm{~s}, 12 \mathrm{H}, \mathrm{Me}), 7.04(\mathrm{~s}, 4 \mathrm{H}, 3-\mathrm{H}), 7.29$ (br t, $J=$ $7 \mathrm{~Hz}, 2 \mathrm{H}, 4-\mathrm{H}), 8.61$ (d, $J=478 \mathrm{~Hz}, 1 \mathrm{H}, \mathrm{PH}) .-{ }^{13} \mathrm{C}$ NMR $\left(\mathrm{CDCl}_{3}, 100 \mathrm{MHz}\right): \delta=20.74(\mathrm{~d}, J=8.0 \mathrm{~Hz}), 129.32(\mathrm{~d}$, $J=98 \mathrm{~Hz}), 129.71(\mathrm{~d}, J=9.6 \mathrm{~Hz}), 131.81(\mathrm{~d}, J=2.4 \mathrm{~Hz})$, 141.77 (d, $J=10.4 \mathrm{~Hz}) .-{ }^{31} \mathrm{P}$ NMR $\left(\mathrm{CDCl}_{3}, 161 \mathrm{MHz}\right): \delta=$ $+10.88(\mathrm{~d}, J=478 \mathrm{~Hz})$.

\section{Synthesis of bis(2,6-dimethylphenyl)phosphine (1g)}

Compound 1g was synthesized with a yield of $69 \%$ from bis(2,6-dimethylphenyl)phosphine oxide by stirring at $70{ }^{\circ} \mathrm{C}$ with triisobutylaluminum in toluene for $48 \mathrm{~h}$, by the known procedure [25]. White crystals. $-{ }^{1} \mathrm{H}$ NMR $\left(\mathrm{C}_{6} \mathrm{D}_{6}\right.$, $400 \mathrm{MHz}): \delta=2.22\left(\mathrm{~s}, 12 \mathrm{H}, \mathrm{CH}_{3}\right), 5.26(\mathrm{~d}, J=231 \mathrm{~Hz}$, $1 \mathrm{H}, \mathrm{PH}), 6.83(\mathrm{dd}, J=7.4 \mathrm{~Hz}, J=2.3 \mathrm{~Hz}, 4 \mathrm{H}, 3-\mathrm{H}), 6.97(\mathrm{t}$, $J=7.4 \mathrm{~Hz}, 2 \mathrm{H}, 4-\mathrm{H}) .-{ }^{13} \mathrm{C}\left\{{ }^{1} \mathrm{H}\right\} \mathrm{NMR}\left(\mathrm{C}_{6} \mathrm{D}_{6}, 100 \mathrm{MHz}\right)$ : $\delta=22.93\left(\mathrm{~d}, J=10.4 \mathrm{~Hz}, \mathrm{CH}_{3}\right), 128.48(\mathrm{~s}, 4-\mathrm{C}), 128.63(\mathrm{~d}$, $J=2.4 \mathrm{~Hz}, 3-\mathrm{C}), 133.38$ (d, $J=17.7 \mathrm{~Hz}, 1-\mathrm{C}), 142.56$ (d, $J=$ 12.0 Hz, 2-C). - ${ }^{31} \mathrm{P}$ NMR $\left(\mathrm{C}_{6} \mathrm{D}_{6}, 161 \mathrm{MHz}\right): \delta=-91.60$ $(\mathrm{d}, J=231 \mathrm{~Hz})$

Synthesis of rac-2-(acetoxyimino)-3,3-dimethyl-2,3-dihydro1H-inden-1-yl acetate

A three-necked $1 \mathrm{~L}$ flask equipped with a reflux condenser was charged with a solution of 2-(hydroxyimino)3,3-dimethyl-2,3-dihydro-1H-inden-1-one [26] (18.4 g, $97 \mathrm{mmol}$, recrystallized from toluene) in $460 \mathrm{~mL}$ of methanol (under nitrogen) and cooled to $-20{ }^{\circ} \mathrm{C} . \mathrm{NaBH}_{4}$ (16.56 $\mathrm{g}, 438 \mathrm{mmol}$ ) was added, and the mixture was stirred for $1 \mathrm{~h}$ with cooling (the reaction is so vigorous, that reflux begins), then for $10 \mathrm{~h}$ in an ice bath. The mixture was evaporated in vacuo and suspended in $368 \mathrm{~mL}$ of pyridine (with vigorous shaking under nitrogen). Acetic anhydride (184 mL) was added, and vigorous shaking continued, resulting in a violet color which changed to yellow within $30 \mathrm{sec}$. After $12 \mathrm{~h}$ the mixture was evaporated in vacuo, and the residue was triturated in $800 \mathrm{~mL}$ of water to give crude rac-2-(acetoxyimino)-3,3-dimethyl-2,3dihydro- $1 H$-inden-1-yl acetate. It was recrystallized from a mixture toluene/hexane $(1: 3)$ to give white crystals with a yield of $70 \%$.

Synthesis of rac-cis-2-amino-3,3-dimethyl-2,3-dihydro-1Hinden-1-ol

A three-necked $100 \mathrm{~mL}$ flask equipped a with reflux condenser was charged with a solution of rac-2(acetoxyimino)-3,3-dimethyl-2,3-dihydro- $1 H$-inden-1-yl ac- etate $(1 \mathrm{~g}, 3.63 \mathrm{mmol})$ in $20 \mathrm{~mL}$ THF (under nitrogen) and cooled to $-20{ }^{\circ} \mathrm{C}$. The borane-dimethylsulfide complex (94\%, Acros, $1.4 \mathrm{~mL}, 14.72 \mathrm{mmol}$ ) was added, and the mixture was heated and refluxed for $3 \mathrm{~h}$, then cooled to $-20{ }^{\circ} \mathrm{C}$, and $1 \mathrm{~N} \mathrm{HCl}(3.4 \mathrm{~mL})$ was added under air which resulted in refluxing. After cooling, the mixture was poured into $2 \mathrm{~N} \mathrm{KOH}$ and five times extracted with $\mathrm{CH}_{2} \mathrm{Cl}_{2}$. The organic extracts were dried with $\mathrm{Na}_{2} \mathrm{SO}_{4}$, filtered and evaporated, giving pure white rac-cis-2-amino-3,3-dimethyl2,3-dihydro- $1 H$-inden-1-ol. This substance is very unstable and epimerizes upon storage, and should be used within $2-3 \mathrm{~d}$. The method can be scaled up to $20 \mathrm{~g}$ of $\mathrm{rac}-2-$ (acetoxyimino)-3,3-dimethyl-2,3-dihydro- $1 H$-inden-1-yl acetate. Although in the original article [27] the use of the borane-THF complex is described, this leads to a mixture, where the target compound was not detected. A communication with Atsushi Sudo (author of article [27]) revealed that the borane-dimethylsulfide complex should be used.

\section{Synthesis of (3aR,8bS)-2-(2-fluorophenyl)-4,4-dimethyl- 4,8b-dihydro-3aH-indeno[2,1-d]oxazole (2h)}

rac-cis-2-Amino-3,3-dimethyl-2,3-dihydro-1H-inden-1ol was resolved as described in the literature [27]. In absolute dioxane under nitrogen $(1 S, 2 R)$-2-amino-3,3-dimethyl2,3-dihydro- $1 H$-inden-1-ol (1.665 g, $9.4 \mathrm{mmol})$ and $\mathrm{NEt}_{3}$ (2.6 mL, $19 \mathrm{mmol}$ ) were dissolved. With cooling to $0{ }^{\circ} \mathrm{C}$, 2-fluorobenzoyl chloride $(1.2 \mathrm{~mL}, 9.9 \mathrm{mmol})$ was added, and the mixture was stirred for $8 \mathrm{~h}$ at r.t. $\mathrm{SOCl}_{2}(13.4 \mathrm{~mL}$, $184.7 \mathrm{mmol}$ ) was added (cooling to $0{ }^{\circ} \mathrm{C}$ ), and the mixture was stirred for $2 \mathrm{~h}$, then evaporated in vacuo at r.t. The residue was suspended in $5 \mathrm{~N} \mathrm{NaOH}$ and extracted five times with $\mathrm{CH}_{2} \mathrm{Cl}_{2}$. After drying of the extracts with $\mathrm{Na}_{2} \mathrm{SO}_{4}$, filtration and evaporation of the solvent the residue was redissolved in absolute $\mathrm{Et}_{2} \mathrm{O} . \mathrm{Na}_{2} \mathrm{SO}_{4}$ ( $3.4 \mathrm{~g}, 23.9 \mathrm{mmol}$ ) and $\mathrm{NaOH}$ dust (Aldrich, $3.4 \mathrm{~g}, 85 \mathrm{mmol}$ ) were added, and the mixture was stirred for $48 \mathrm{~h}$ at r.t. in a sealed flask. Water was added, and the organic layer was separated. Adsorption on silica with subsequent column chromatography on $200 \mathrm{~g}$ of silica $\left(\mathrm{Et}_{2} \mathrm{O}\right.$-pentane $\left.2: 3\right)$ gave crystalline off-white ( $3 a R, 8 b S)$-2-(2-fluorophenyl)-4,4dimethyl-4,8b-dihydro-3a $H$-indeno[2,1-d]oxazole (2h) with a yield of $30 \%$. Unfortunately, the target compound is only a by-product. The formula of the main product, which is less polar and elutes first from the column, was not assigned. The spectral properties of $\mathbf{2 h}$ correspond to those published [28].

\section{General procedure A for the synthesis of $4 \boldsymbol{a}-\boldsymbol{e}, \mathbf{4 f}, \mathbf{4 k}$ and $\mathbf{4 j}$}

Diphenylphosphine (1a) (61 mg, $0.33 \mathrm{mmol}$, for complexes $\mathbf{4 a}-\mathbf{d}, \mathbf{4 k}, \mathbf{4 j})$ or di(o-tolyl)phosphine (1e) $(71 \mathrm{mg}$, $0.33 \mathbf{m m o l}$, for complexes $\mathbf{4 e}, \mathbf{4 f})$ was dissolved in diethyl ether ( $4 \mathrm{~mL})$, and $n$-BuLi (1.6 M solution in hexane, $0.21 \mathrm{~mL}$, 
$0.33 \mathrm{mmol}$ ) was added at r.t., and the yellow mixture was stirred for $5 \mathrm{~min}$. Oxazoline (2a-d, 2k, $0.3 \mathrm{mmol})$ was added to the reaction mixture, and the reaction mixture was stirred overnight. At this point, gas chromatography with a masssensitive analyzer was performed, which showed a conversion of $\mathbf{2}$ of over $90 \%$ into ligand $\mathbf{3}$. The mixture was evaporated in a stream of nitrogen. $[\operatorname{Ir}(\mathrm{COD}) \mathrm{Cl}]_{2}(100.8 \mathrm{mg}$, $0.15 \mathrm{mmol})$ and $\mathrm{CH}_{2} \mathrm{Cl}_{2}(3 \mathrm{~mL})$ were added to the residue, and the mixture was refluxed for $2 \mathrm{~h}$ and cooled. The anion exchange can be carried out in air. The procedure can be scaled up to $400 \mathrm{mg}$ of $[\mathrm{Ir}(\mathrm{COD}) \mathrm{Cl}]_{2}$. The complexes of this type (with various anions) are found to be unstable in toluene on storage (toluene being metallated).

\section{Exchange of Cl by BARF}

NaBARF (292 mg, $0.33 \mathrm{mmol}$ ) was added to the reaction mixture with stirring at r.t. for $1-3 \mathrm{~h}$. The exchange could be monitored by TLC on silica gel eluting with dichloromethane $\left(R_{\mathrm{f}}\right.$ of $[\operatorname{Ir}(\mathrm{COD}) \mathrm{Cl}(\mathrm{Phox})]$ is 0 , that of [Ir(COD)(Phox)]BARF is $0.75-1)$. Then silica gel $(1 \mathrm{~g})$ was added, and the mixture was evaporated under vacuum at r.t. This silica was placed on top of the column filled with $20 \mathrm{~g}$ of silica gel, and the desired colored complex was eluted with $\mathrm{CH}_{2} \mathrm{Cl}_{2}$. The eluant was evaporated in vacuo (without heating), and the complex was dried in a vacuum $\left(10^{-2}\right.$ mbar).

\section{Exchange of $\mathrm{Cl}$ by $\mathrm{PF}_{6}$}

A solution of $\mathrm{KPF}_{6}(184 \mathrm{mg}, 1 \mathrm{mmol})$ in water $(2 \mathrm{~mL})$ was added to the reaction mixture. The two-phase system was vigorously stirred for $2 \mathrm{~h}$, the exchange being monitored with TLC on silica gel with $\mathrm{CH}_{2} \mathrm{Cl}_{2}-\mathrm{MeOH}(20: 1)$ as eluent. The organic layer was separated, and the aqueous residue was extracted 5 times with $\mathrm{CH}_{2} \mathrm{Cl}_{2}$. Combined organic extracts were dried over $\mathrm{Na}_{2} \mathrm{SO}_{4}$, filtered and evaporated at r.t. The residue was redissolved in a minimum amount of $\mathrm{CH}_{2} \mathrm{Cl}_{2}$, and the target complex was precipitated with $100 \mathrm{~mL}$ of $\mathrm{Et}_{2} \mathrm{O}$, filtered, washed off from the filter with $\mathrm{CH}_{2} \mathrm{Cl}_{2}$, evaporated at r.t. and dried in a vacuum $\left(10^{-2}\right.$ mbar $)$.

\section{(2-(2-(Diphenylphosphino)phenyl)-4,5-dihydrooxazole)- ( $\eta^{4}$-1,5-cyclooctadiene)iridium(I) tetrakis(3,5-bis(trifluoro- methyl)phenyl)borate (4a)}

Yield: $74 \%$. Red crystals. Unstable on storage at r.t. even in crystalline form (should be stored at $-20{ }^{\circ} \mathrm{C}$ ). ${ }^{1} \mathrm{H} \mathrm{NMR}\left(\mathrm{CDCl}_{3}, 600 \mathrm{MHz}\right): \delta=1.93\left(\mathrm{~m}, 2 \mathrm{H}, \mathrm{a}-4-\mathrm{H}_{\mathrm{COD}}\right.$ and a-8- $\left.\mathrm{H}_{\mathrm{COD}}\right), 2.05\left(\mathrm{~m}, 2 \mathrm{H}, \mathrm{a}-3-\mathrm{H}_{\mathrm{COD}}\right.$ and $\left.\mathrm{a}-7-\mathrm{H}_{\mathrm{COD}}\right)$,

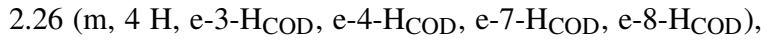
3.16 (br s, $2 \mathrm{H}, 5-$ and 6-H $\mathrm{COD}), 4.09(\mathrm{t}, J=10 \mathrm{~Hz}, 2 \mathrm{H}$, $\left.\mathrm{NCH}_{2}\right), 4.48\left(\mathrm{t}, J=10 \mathrm{~Hz}, 2 \mathrm{H}, \mathrm{OCH}_{2}\right), 5.08$ (br s, $2 \mathrm{H}$, 1 - and $\left.2-\mathrm{H}_{\mathrm{COD}}\right), 7.43(\mathrm{dd}, J=11.4 \mathrm{~Hz}, J=8.2 \mathrm{~Hz}, 4 \mathrm{H}$, $\left.2^{\prime}-\mathrm{H}\right), 7.49\left(\mathrm{~m}, 6 \mathrm{H}, 3-, 4-\right.$ and $\left.3^{\prime}-\mathrm{H}\right), 7.60(\mathrm{~m}, 3 \mathrm{H}, 5-$ and $\left.4^{\prime}-\mathrm{H}\right), 8.05(\mathrm{~m}, 1 \mathrm{H}, 6-\mathrm{H})$, and the signals of BARF. ${ }^{13} \mathrm{C}\left\{{ }^{1} \mathrm{H}\right\} \mathrm{NMR}\left(\mathrm{CDCl}_{3}, 150 \mathrm{MHz}\right): \delta=32.13(\mathrm{~d}, J=3.4 \mathrm{~Hz}$, 4- and 8- $\mathrm{CH}_{2 \mathrm{COD}}$ ), 29.70 (3- and 7- $\mathrm{CH}_{2} \mathrm{COD}$ ), $54.55\left(\mathrm{NCH}_{2}\right)$, 64.28 (5- and 6- $\left.\mathrm{CH}_{\mathrm{COD}}\right), 68.39\left(\mathrm{OCH}_{2}\right), 95.14(\mathrm{~d}, J=$ $11.5 \mathrm{~Hz}, 1-2$ and $\left.2-\mathrm{CH}_{\mathrm{COD}}\right), 126.20\left(\mathrm{~d}, J=60 \mathrm{~Hz}, 1^{\prime}-\mathrm{C}\right)$, $128.68(\mathrm{~d}, J=8.8 \mathrm{~Hz}, 1-\mathrm{C}), 129.36\left(\mathrm{~d}, J=9.9 \mathrm{~Hz}, 3^{\prime}-\mathrm{CH}\right)$, 129.39 (d, $J=46.1 \mathrm{~Hz}, 2-\mathrm{C}), 132.15(\mathrm{~d}, J=1.6 \mathrm{~Hz}, 5-\mathrm{CH})$, 132.47 (d, $\left.J=2.4 \mathrm{~Hz}, 4^{\prime}-\mathrm{CH}\right), 133.23(\mathrm{~d}, J=9.9 \mathrm{~Hz}, 3-\mathrm{CH})$, 133.35 (d, $J=8.0 \mathrm{~Hz}, 6-\mathrm{CH}), 133.89$ (d, $J=6.9 \mathrm{~Hz}, 4-\mathrm{CH})$, $134.18\left(\mathrm{~d}, J=12.1 \mathrm{~Hz}, 2^{\prime}-\mathrm{CH}\right), 165.68(\mathrm{~d}, J=8.0 \mathrm{~Hz}$, $\mathrm{N}=\mathrm{C})$, and the signals of BARF. $-{ }^{31} \mathrm{P} \mathrm{NMR}\left(\mathrm{CDCl}_{3}\right.$, $161 \mathrm{MHz}): \delta=+16.1$. - HRMS ESI/FT-ICR: isotope cluster 630-634, found (calcd.): 630.1679, $66 \%$ (630.1671, $60 \%) ; 631.1721,21 \%(633.1728,31 \%) ; 631.1856,12 \%$ $(631.1704,19 \%) ; 632.1688,100 \%(632.1694,100 \%)$; 633.1714, $33 \%$ (633.1728, $31 \%)$; 634.1739, $7 \%$ (634.1761, $5 \%)$.

Racemic (2-(2-(diphenylphosphino)phenyl)-4-methyl4,5-dihydrooxazole)-( $\eta^{4}$-1,5-cyclooctadiene)iridium(I) tetrakis(3,5-bis(trifluoromethyl)phenyl)borate (4b)

Yield: $80 \%$. Red crystals. Very stable on storage at r.t. even in $\mathrm{CDCl}_{3}$ solution (6 month). $-{ }^{1} \mathrm{H}$ NMR $\left(\mathrm{CDCl}_{3}\right.$, $600 \mathrm{MHz}): \delta=1.05(\mathrm{~d}, J=5.7 \mathrm{~Hz}, \mathrm{Me}), 1.47(\mathrm{nrm}, 1 \mathrm{H}$, a-4-H $\left.\mathrm{COD}_{\mathrm{C}}\right), 1.65$ (nrm, $1 \mathrm{H}$, a-8- $\left.\mathrm{H}_{\mathrm{COD}}\right), 2.03(\mathrm{nrm}, 1 \mathrm{H}$, e-4- $\mathrm{H}_{\mathrm{COD}}$ ), 2.06 (nrm, $1 \mathrm{H}, \mathrm{e}-8-\mathrm{H}_{\mathrm{COD}}$ ), 2.45 (nrm, $3 \mathrm{H}$, a-7- $\mathrm{H}_{\mathrm{COD}}$ and 3- $\mathrm{H}_{\mathrm{COD}}$ ), 2.53 (nrm, $1 \mathrm{H}, \mathrm{e}-7-\mathrm{H}_{\mathrm{COD}}$ ), 3.14 (br m, $1 \mathrm{H}, 5-\mathrm{H}_{\mathrm{COD}}$ ), 3.36 (br m, $1 \mathrm{H}, 6-\mathrm{H}_{\mathrm{COD}}$ ), 4.18 (dd, $J=$ $9.0 \mathrm{~Hz}, J=3.9 \mathrm{~Hz}, 1 \mathrm{H}, \mathrm{OCH}_{2}$ ), 4.27 (br s, $1 \mathrm{H}, \mathrm{NCHMe}$ ), $4.46\left(\mathrm{~d}, J=9.0 \mathrm{~Hz}, 1 \mathrm{H}, \mathrm{OCH}_{2}\right), 4.97$ (br s, $2 \mathrm{H}, 1-$ and $\left.2-\mathrm{H}_{\mathrm{COD}}\right), 7.14\left(\mathrm{dd}, J=11.3 \mathrm{~Hz}, J=6.6 \mathrm{~Hz}, 2 \mathrm{H}, 2^{\prime}-\mathrm{H}\right)$, 7.41 (nrm, $1 \mathrm{H}, 3-\mathrm{H}), 7.46$ (nrm, $\left.2 \mathrm{H}, 3^{\prime}-\mathrm{H}\right), 7.47$ (nrm, $1 \mathrm{H}$, $\left.4^{\prime}-\mathrm{H}\right), 7.48$ (nrm, $\left.2 \mathrm{H}, 3^{\prime \prime}-\mathrm{H}\right), 7.55$ (nrm, $\left.1 \mathrm{H}, 4^{\prime \prime}-\mathrm{H}\right), 7.60$ (nrm, $4 \mathrm{H}, 4-$, 5- and 2" $-\mathrm{H}), 8.07$ (m, $1 \mathrm{H}, 6-\mathrm{H})$, and the signals of BARF. $-{ }^{13} \mathrm{C}\left\{{ }^{1} \mathrm{H}\right\}$ NMR $\left(\mathrm{CDCl}_{3}, 150 \mathrm{MHz}\right): \delta=$ $23.16(\mathrm{Me}), 26.47$ (8- $\left.\mathrm{CH}_{2 \mathrm{COD}}\right), 28.59$ (4- $\left.\mathrm{CH}_{2 \mathrm{COD}}\right), 32.22$ (3- $\left.\mathrm{CH}_{2 \mathrm{COD}}\right), 36.06$ (7- $\left.\mathrm{CH}_{2 \mathrm{COD}}\right), 61.52$ (NCHMe), 63.80 (6- $\left.\mathrm{CH}_{\mathrm{COD}}\right), 63.92\left(5-\mathrm{CH}_{\mathrm{COD}}\right), 74.24\left(\mathrm{OCH}_{2}\right), 93.54$ (d, $J=$ $\left.13.2 \mathrm{~Hz}, 1-\mathrm{CH}_{\mathrm{COD}}\right), 96.49$ (d, $\left.J=12.1 \mathrm{~Hz}, 2-\mathrm{CH}_{\mathrm{COD}}\right), 117.5$ (br s, 4-CHBARF), 121.81 (d, $\left.J=58.3 \mathrm{~Hz}, 1^{\prime}-\mathrm{C}\right), 128.65$ (d, $J=29.7 \mathrm{~Hz}, 2-\mathrm{C}), 128.98$ (d, $\left.J=11.0 \mathrm{~Hz}, 3^{\prime}-\mathrm{CH}\right), 129.12$ (d, $\left.J=50.6 \mathrm{~Hz}, 1^{\prime \prime}-\mathrm{C}\right), 129.60$ (d, $\left.J=11.0 \mathrm{~Hz}, 3^{\prime \prime}-\mathrm{CH}\right)$, 129.70 (d, $J=15.4 \mathrm{~Hz}, 1-\mathrm{C}), 132.23\left(\mathrm{~d}, J=3.3 \mathrm{~Hz}, 4^{\prime}-\mathrm{CH}\right)$, 132.25 (br s, 5-CH), $132.70\left(\mathrm{~d}, J=2.2 \mathrm{~Hz}, 4^{\prime \prime}-\mathrm{CH}\right), 133.11$ (d, $\left.J=9.9 \mathrm{~Hz}, 2^{\prime}-\mathrm{CH}\right), 133.39$ (br s, 3-CH), 133.46 (d, $J=7.7 \mathrm{~Hz}, 6-\mathrm{CH}), 133.99$ (d, $J=6.6 \mathrm{~Hz}, 4-\mathrm{CH}), 134.96$ (d, $\left.J=12.1 \mathrm{~Hz}, 2^{\prime \prime}-\mathrm{CH}\right), 163.73(\mathrm{~d}, J=6.6 \mathrm{~Hz}, \mathrm{~N}=\mathrm{C})$, and the signals of BARF. $-{ }^{31} \mathrm{P}$ NMR $\left(\mathrm{CDCl}_{3}, 161 \mathrm{MHz}\right)$ : $\delta=+17.6$. - HRMS ESI/FT-ICR: isotope cluster 644-648, found (calcd.): 644.1833, $57 \%(644.1827,60 \%)$; 645.1880, $18 \%$ (645.1861, 19\%); 646.1851, $100 \%$ (646.1851, $100 \%)$; 647.1901, $34 \%$ (647.1884, $33 \%) ; 648.1949,6 \%$ (648.1918, $5 \%)$. 
((4S)-2-(2-(Diphenylphosphino)phenyl)-4-isopropyl4,5-dihydrooxazole $)-\left(\eta^{4}-1,5\right.$-cyclooctadiene)iridium(I) tetrakis(3,5-bis(trifluoromethyl)phenyl)borate (4c)

Yield: $81 \%$ (best yield found in literature is $91 \%$ [3]). Red crystals. Very stable on storage at r.t. even in $\mathrm{CDCl}_{3}$ solution (6 month).

((4S)-2-(2-(-Diphenylphosphino)phenyl)-4-tert-butyl4,5-dihydrooxazole)-( $\eta^{4}-1,5$-cyclooctadiene $)$ iridium $(I)$ tetrakis(3,5-bis(trifluoromethyl)phenyl)borate (4d)

Yield: $79.7 \%$. Red crystals. Very stable on storage at r.t. even in $\mathrm{CDCl}_{3}$ solution (6 month). $-[\alpha]_{\mathrm{D}}^{21}=-155(c=0.105$, $\left.\mathrm{CHCl}_{3}\right) .-{ }^{1} \mathrm{H}$ NMR $\left(\mathrm{CDCl}_{3}, 600 \mathrm{MHz}\right): \delta=0.63$ (s, $9 \mathrm{H}$, $\mathrm{Me}), 1.43\left(\mathrm{nrm}, 1 \mathrm{H}, \mathrm{a}-4-\mathrm{H}_{\mathrm{COD}}\right) 1.6\left(\mathrm{nrm}, 1 \mathrm{H}, \mathrm{a}-8-\mathrm{H}_{\mathrm{COD}}\right)$, 2.0 (nrm, $2 \mathrm{H}, \mathrm{e}-4-$ and e-8- $\mathrm{H}_{\mathrm{COD}}$ ), 2.47 (nrm, $2 \mathrm{H}$, a-3and a-7- $\left.\mathrm{H}_{\mathrm{COD}}\right), 2.40\left(\mathrm{nrm}, 1 \mathrm{H}, \mathrm{e}-3-\mathrm{H}_{\mathrm{COD}}\right), 2.55(\mathrm{nrm}, 1 \mathrm{H}$, e-7-H $\mathrm{COD}_{\text {) }}, 3.04$ (br s, $1 \mathrm{H}, \mathrm{NOE}$ with $7.11 \mathrm{ppm}, 5-\mathrm{H}_{\mathrm{COD}}$ ), 3.5 (br s, $1 \mathrm{H}$, NOE with $7.46 \mathrm{ppm}, 6-\mathrm{H}_{\mathrm{COD}}$ ), 3.94 (dd, $J=$ $9.4 \mathrm{~Hz}, J=2.6 \mathrm{~Hz}, \mathrm{NCHtBu}) 4.32(\mathrm{t}, J=9.4 \mathrm{~Hz}, 1 \mathrm{H}$, $\left.\mathrm{OCH}_{2}\right), 4.58\left(\mathrm{dd}, J=9.4 \mathrm{~Hz}, J=2.6 \mathrm{~Hz}, 1 \mathrm{H}, \mathrm{OCH}_{2}\right)$, 4.95 (br m, $2 \mathrm{H}, 1-$ and 2- $\mathrm{H}_{\mathrm{COD}}$ ), 7.11 (br m, $2 \mathrm{H}, 2^{\prime}-\mathrm{H}$ ), 7.32 (nrm, $1 \mathrm{H}, 3-\mathrm{H}), 7.43$ (nrm, $\left.2 \mathrm{H}, 3^{\prime}-\mathrm{H}\right), 7.46$ (nrm, $\left.2 \mathrm{H}, 2^{\prime \prime}-\mathrm{H}\right), 7.49$ (nrm, $\left.1 \mathrm{H}, 4^{\prime}-\mathrm{H}\right), 7.50$ (nrm, $\left.2 \mathrm{H}, 3^{\prime \prime}-\mathrm{H}\right)$, $7.55\left(\mathrm{nrm}, 1 \mathrm{H}, 4^{\prime \prime}-\mathrm{H}\right), 7.62(\mathrm{nrm}, 2 \mathrm{H}, 4-$ and 5-H), 8.20 (m, $1 \mathrm{H}, 6-\mathrm{H})$, and the signals of BARF. $-{ }^{13} \mathrm{C}\left\{{ }^{1} \mathrm{H}\right\}$ NMR $\left(\mathrm{CDCl}_{3}, 150 \mathrm{MHz}\right): \delta=25.09(\mathrm{Me}), 25.51\left(8-\mathrm{CH}_{2 \mathrm{COD}}\right)$, $28.16\left(4-\mathrm{CH}_{2 \mathrm{COD}}\right), 32.70\left(3-\mathrm{CH}_{2 \mathrm{COD}}\right), 34.42\left(\mathrm{CMe}_{3}\right), 36.8$ (7- $\left.\mathrm{CH}_{2} \mathrm{COD}\right), 62.74\left(5-\mathrm{CH}_{\mathrm{COD}}\right), 63.37\left(6-\mathrm{CH}_{\mathrm{COD}}\right), 69.82$ $\left(\mathrm{OCH}_{2}\right), 74.47(\mathrm{NCH} t \mathrm{Bu}), 93.28\left(\mathrm{~d}, J=13.8 \mathrm{~Hz}, 1-\mathrm{CH}_{\mathrm{COD}}\right)$, $97.57\left(\mathrm{~d}, J=10.3 \mathrm{~Hz}, 2-\mathrm{CH}_{\mathrm{COD}}\right), 122.31(\mathrm{~d}, J=57.4 \mathrm{~Hz}$, $\left.1^{\prime}-\mathrm{C}\right), 127.61$ (d, $\left.J=48.2 \mathrm{~Hz}, 2-\mathrm{C}\right), 128.83(\mathrm{~d}, J=10.3 \mathrm{~Hz}$, $\left.3^{\prime}-\mathrm{CH}\right), 129.12(\mathrm{~d}, J=13.8 \mathrm{~Hz}, 1-\mathrm{C}), 129.60(\mathrm{~d}, J=51.6 \mathrm{~Hz}$, $\left.1^{\prime \prime}-\mathrm{C}\right), 129.70$ (d, $\left.J=11.5 \mathrm{~Hz}, 3^{\prime \prime}-\mathrm{CH}\right), 132.09\left(4^{\prime}-\mathrm{CH}\right)$, 132.58 (d, $J=1.6 \mathrm{~Hz}, 5-\mathrm{CH}), 132.62\left(4^{\prime \prime}-\mathrm{CH}\right), 133.19$ (d, $\left.J=10.3 \mathrm{~Hz}, 2^{\prime}-\mathrm{CH}\right), 133.98(\mathrm{~d}, J=8.0 \mathrm{~Hz}, 6-\mathrm{CH}), 134.20$ (d, $\left.J=14.9 \mathrm{~Hz}, 2^{\prime \prime}-\mathrm{CH}\right), 134.23(\mathrm{~d}, J=6.9 \mathrm{~Hz}, 4-\mathrm{CH})$, $134.93(\mathrm{~d}, J=2.4 \mathrm{~Hz}, 3-\mathrm{CH}), 164.03(\mathrm{~d}, J=4.6 \mathrm{~Hz}, \mathrm{~N}=\mathrm{C})$, and the signals of BARF. $-{ }^{31} \mathrm{P}$ NMR $\left(\mathrm{CDCl}_{3}, 161 \mathrm{MHz}\right)$ : $\delta=+17.5$. - HRMS ESI/FT-ICR: isotope cluster 686-690, found (calcd.): 686.2380, $53 \%(686.2297,60 \%) ; 687.2416$, $13 \%$ (687.2330, $21 \%) ; 688.2323,100 \%$ (688.2320, $100 \%)$; 689.2315, $44 \%$ (689.2354, $36 \%) ; 690.2344,5 \%$ (690.2387, $6 \%)$.

((4S)-2-(2-(Di(o-tolyl)phosphino)phenyl)-4-isopropyl4,5-dihydrooxazole)-( $\eta^{4}$-1,5-cyclooctadiene)iridium(I) tetrakis(3,5-bis(trifluoromethyl)phenyl)borate (4e)

Yield: $85 \%$. Red crystals. Very stable on storage at r.t. even in $\mathrm{CDCl}_{3}$ solution (6 month). $-[\alpha]_{\mathrm{D}}^{20}=-97(c=0.13$, $\left.\mathrm{CHCl}_{3}\right) .-{ }^{31} \mathrm{P}$ NMR $(1,2,4$-trichlorobenzene, $161 \mathrm{MHz}$, $\left.140{ }^{\circ} \mathrm{C}\right): \delta=+12.5 .-{ }^{1} \mathrm{H} \mathrm{NMR}\left(\mathrm{CDCl}_{3}, 600 \mathrm{MHz}\right.$, r. t., full assignment is not possible): $\delta=0.05(\mathrm{br} \mathrm{s}, 3 \mathrm{H}), 0.87$ (br s, $3 \mathrm{H}, \mathrm{Me}$ ), 1.41 (br s, $1 \mathrm{H}, \mathrm{Me}$ ), 1.58 (br m, $1 \mathrm{H}$ ), 1.95 (br s, $1 \mathrm{H}) 2.04$ (br m, $2 \mathrm{H}, \mathrm{CHMe}_{2}$ and e-3- $\mathrm{H}_{\mathrm{COD}}$ ), 2.31 (br s, $1 \mathrm{H}$ ), 2.35 (s, $6 \mathrm{H}, 2^{\prime}$-Me and $2^{\prime \prime}-\mathrm{Me}$ ), 2.42 (br m, $2 \mathrm{H}$, e-8- $\mathrm{CH}_{\mathrm{COD}}$ ), 3.30 (br s, $2 \mathrm{H}, 5-$ and 6- $\mathrm{H}_{\mathrm{COD}}$ ), 4.15 (br s, $\left.1 \mathrm{H}, \mathrm{OCH}_{2}\right), 4.32$ (t, $\left.J=9.54 \mathrm{~Hz}, 1 \mathrm{H}, \mathrm{OCH}_{2}\right), 4.43$ (br s, $1 \mathrm{H}, \mathrm{NCH}$ ), 4.68 (br q, $J=6.7 \mathrm{~Hz}, \mathrm{NOE}$ with $2.05 \mathrm{ppm}$, $1 \mathrm{H}, 1-\mathrm{CH}_{\mathrm{COD}}$ ), 4.98 (br s, $1 \mathrm{H}, 2-\mathrm{CH}_{\mathrm{COD}}$ ), 7.21 (br s, $2 \mathrm{H}$, 6'-H), 7.37 (br s, $2 \mathrm{H}, 3^{\prime}-\mathrm{H}$ ), 7.43 (br s, $2 \mathrm{H}, 4^{\prime}-\mathrm{H}$ ), 7.58 (br s, $3 \mathrm{H}, 3-$, 4- and 5-H), 8.09 (br m, $1 \mathrm{H}, 6-\mathrm{H}$ ), and the signals of BARF. $-{ }^{13} \mathrm{C}\left\{{ }^{1} \mathrm{H}\right\} \mathrm{NMR}\left(\mathrm{CDCl}_{3}, 150 \mathrm{MHz}\right.$, r. t., assignment is not possible): $\delta=12.31,13.26,18.71,24.0$, 27.90, 29.71, 31.17, 32.41, 21.97, 35.30, 36.16, 68.18, 70.32, 68.9, 94.6, 127.08 (d, $J=8 \mathrm{~Hz}), 129.51,132.11,132.46$ (d, $J=8 \mathrm{~Hz}), 132.62,133.66,133.71,133.81(\mathrm{~d}, J=8 \mathrm{~Hz})$, $135.3,163.88$, and the signals of BARF. $-{ }^{31} \mathrm{P} \mathrm{NMR}\left(\mathrm{CDCl}_{3}\right.$, $161 \mathrm{MHz}$, r. t.): 8.54 (br s, $0.9 \mathrm{P}), 16.14$ (br s, $1 \mathrm{P}$ ). $-{ }^{1} \mathrm{H} \mathrm{NMR}$ $\left(\mathrm{CDCl}_{3}, 400 \mathrm{MHz},-40{ }^{\circ} \mathrm{C}\right): \delta=-0.09(\mathrm{~d}, J=6.64 \mathrm{~Hz}$, $1 \mathrm{H}), 0.12(\mathrm{~d}, J=6.6 \mathrm{~Hz}, 1.6 \mathrm{H}), 0.84(\mathrm{~d}, J=7 \mathrm{~Hz}, 1.3 \mathrm{H})$, $0.92(\mathrm{~d}, J=6.6 \mathrm{~Hz}, 1.8 \mathrm{H}), 1.37$ (br s, $1.2 \mathrm{H}), 1.55$ (br s, $1.3 \mathrm{H}$ ), $1.85-2.04$ (br m, $4.9 \mathrm{H}$ ), $2.22-2.57$ (br m, 8.6 H), 2.82 (br s, $0.4 \mathrm{H}$ ), 3.15 (br s, $0.4 \mathrm{H}$ ), 3.28-3.39 (br m, $1.65 \mathrm{H}), 4.1-4.2$ (br m, $0.9 \mathrm{H}), 4.32-4.44$ (br m, $1.3 \mathrm{H}$ ), 4.50 (br d, $J=7 \mathrm{~Hz}, 0.6 \mathrm{H}$ ), 4.67 (br s, $1 \mathrm{H}), 4.93-5.08$ (br m, 0.9 H), $6.63(\mathrm{~m}, 0.8 \mathrm{H}), 6.91(\mathrm{~m}, 0.7 \mathrm{H}), 7.07(\mathrm{~m}$, $0.7 \mathrm{H}), 7.18-7.26(\mathrm{~m}, 1.7 \mathrm{H}), 7.34-7.70(\mathrm{~m}, 12 \mathrm{H}), 8.07$ (br m, $1 \mathrm{H}), 9.07(\mathrm{~m}, 0.5 \mathrm{H})$, and the signals of BARF. ${ }^{13} \mathrm{C}\left\{{ }^{1} \mathrm{H}\right\}$ NMR $\left(\mathrm{CDCl}_{3}, 150 \mathrm{MHz},-40{ }^{\circ} \mathrm{C}\right): \delta=11.94$, 13.26, 18.69, 23.45 (br s), 23.79 (d, $J=8 \mathrm{~Hz}), 24.67$ (d, $J=5.7 \mathrm{~Hz}), 25.32,26.77$ (d, $J=8 \mathrm{~Hz}), 27.36,27.67,29.70$ (br s), 32.12, 32.24, 32.27, 33.06, 35.38 (br s), 36.23 (br s), 64.07, 65.04, 66.42, 67.51, 67.81, 68.05, 69.66, 69.88, $88.31(\mathrm{~d}, J=12.6 \mathrm{~Hz}), 89.20($ br d, $J=13.8 \mathrm{~Hz}), 94.03$ (d, $J=10.3 \mathrm{~Hz}), 94.76$ (br d, $J=9.2 \mathrm{~Hz}), 117.51(\mathrm{~d}, J=$ $57.0 \mathrm{~Hz}), 117.67,120.39(\mathrm{~d}, J=53.9 \mathrm{~Hz}), 125.99,126.31$ $(\mathrm{d}, J=4.6 \mathrm{~Hz}), 126.43,126.77,126.84(\mathrm{~d}, J=4.6 \mathrm{~Hz})$, $126.99(\mathrm{~d}, J=6.9 \mathrm{~Hz}), 127.07$ (d, $J=8.0 \mathrm{~Hz}), 127.70$ (d, $J=12.6 \mathrm{~Hz}), 127.68,128.29(\mathrm{~d}, J=19.5 \mathrm{~Hz}), 129.17,131.7-$ $132.4(\mathrm{~m}), 133.2-133.7$ (m), 133.89, 134.38, 135.83, 140.57 $(\mathrm{d}, J=9.2 \mathrm{~Hz}), 141.51(\mathrm{~d}, J=9.2 \mathrm{~Hz}), 142.60,142.70$, $140.80,143.45,163.16(\mathrm{~d}, J=4.6 \mathrm{~Hz}), 163.76(\mathrm{~d}, J=$ $8.0 \mathrm{~Hz})$, and the signals of BARF. $-{ }^{31} \mathrm{P} \mathrm{NMR}\left(\mathrm{CDCl}_{3}\right.$, $\left.161 \mathrm{MHz},-40{ }^{\circ} \mathrm{C}\right): \delta=8.21(\mathrm{~s}, 0.75 \mathrm{P}), 15.75(\mathrm{~s}$, 1 P). - HRMS ESI/FT-ICR: isotope cluster 644-648, found (calcd.): 700.2441, $51 \%(700,2453,60 \%) ; 701.2434$, $17 \%$ (701,2487, $22 \%) ; 702.2472,100 \%$ (702,2477, $100 \%)$; 703.2477, $34 \%(703,2510,37 \%) ; 704.2539,6 \%(703,2510$, $7 \%)$.

((4S)-2-(2-(Di(o-tolyl)phosphino)phenyl)-4- tert-butyl4,5-dihydrooxazole $)-\left(\eta^{4}-1,5\right.$-cyclooctadiene)iridium(I) tetrakis(3,5-bis(trifluoromethyl)phenyl)borate (4f)

Yield: $83 \%$ (best yield found in literature is $72 \%$ [15]). Orange crystals, very stable on storage at r.t. even in $\mathrm{CDCl}_{3}$ solution (6 month). 
((4S)-2-(2-(Diphenylphosphino)phenyl)-4-isopropyl4,5-dihydrooxazole)-( $\eta^{4}-1,5$-cyclooctadiene)iridium(I) hexafluorophosphate $(\mathbf{4 j})$

Yield: $78 \%$ (best yield found in literature is $82 \%$ [2]). Red crystals. Unstable on storage in solution, but stable in crystalline state, can be stored at r.t., but better at $-20{ }^{\circ} \mathrm{C}$.

(2-(2-(-Diphenylphosphino)phenyl)- 4,4-dimethyl-4,5dihydrooxazole)-( $\eta^{4}-1,5$-cyclooctadiene)iridium(I)

tetrakis(3,5-bis(trifluoromethyl)phenyl)borate (4k)

Yield: $68 \%$. Red crystals. Very unstable even in crystalline state. Should be stored at $-20{ }^{\circ} \mathrm{C} .-{ }^{1} \mathrm{H} \mathrm{NMR}\left(\mathrm{CDCl}_{3}\right.$, $600 \mathrm{MHz}): \delta=1.31(\mathrm{~s}, 6 \mathrm{H}, \mathrm{Me}), 1.82(\mathrm{nrm}, 2 \mathrm{H}, \mathrm{a}-3-$ and a-7-H $\mathrm{COD}_{\text {) }}, 2.01$ (nrm, $2 \mathrm{H}$, e-3- and e-7-H $\mathrm{COD}$ ), 2.22 (nrm, $4 \mathrm{H}, 4-$ and $8-\mathrm{H}_{\mathrm{COD}}$ ), 3.27 (br s, $2 \mathrm{H}, 5-$ and 6- $\mathrm{H}_{\mathrm{COD}}$ ), 3.87 (s, $2 \mathrm{H}, \mathrm{OCH}_{2}$ ), 5.40 (br s, $2 \mathrm{H}, 1$ - and 2- $\mathrm{H}_{\mathrm{COD}}$ ), 7.31 (br s, $4 \mathrm{H}, 2^{\prime \prime}$ - and $\left.3^{\prime \prime}-\mathrm{H}\right), 7.44(\mathrm{nmr}, 1 \mathrm{H}, 3-\mathrm{H}), 7.48$ (nrm, $3 \mathrm{H}$, $2^{\prime}$ - and $\left.4^{\prime \prime}-\mathrm{H}\right), 7.54$ (br s, $5 \mathrm{H}, 4^{\prime}-\mathrm{H}$ and $\left.4-\mathrm{H}_{\mathrm{BARF}}\right), 7.59$ (nrm, $3 \mathrm{H}, 5-$ and $\left.3^{\prime}-\mathrm{H}\right), 7.60$ (nrm, $\left.1 \mathrm{H}, 4-\mathrm{H}\right), 7.84$ (m, $1 \mathrm{H}$, 6-H), and the signals of BARF. $-{ }^{13} \mathrm{C}\left\{{ }^{1} \mathrm{H}\right\}$ NMR $\left(\mathrm{CDCl}_{3}\right.$, $150 \mathrm{MHz}$ ): $\delta=27.81(\mathrm{Me}), 29.70$ (br s, 4- and $8-\mathrm{CH}_{2 \mathrm{COD}}$ ), 31.90 (br s, 3- and 7- $\mathrm{CH}_{2 \mathrm{COD}}$ ), 61.72 (5- and 6- $\mathrm{CH}_{\mathrm{COD}}$ ), $73.12\left(\mathrm{OCH}_{2}\right), 82.47\left(\mathrm{NCMe}_{2}\right), 93.64(\mathrm{~d}, J=13.2 \mathrm{~Hz}, 1-$ and 2-CH $\left.\mathrm{CHD}_{\mathrm{COD}}\right), 125.29$ (d, $\left.J=41.7 \mathrm{~Hz}, 2-\mathrm{C}\right), 125.74$ (d, $\left.J=60.4 \mathrm{~Hz}, 1^{\prime}-\mathrm{C}\right), 129.52\left(4^{\prime \prime}-\mathrm{CH}\right), 129.28(\mathrm{~d}, J=11.0 \mathrm{~Hz}$, $\left.2^{\prime \prime}-\mathrm{CH}\right), 129.91$ (d, $\left.J=62.6 \mathrm{~Hz}, 1^{\prime \prime}-\mathrm{C}\right), 131.23(\mathrm{~d}, J=5.5 \mathrm{~Hz}$, 1-C), 131.71 (br s, 3-CH), 131.90 (d, $J=7.7 \mathrm{~Hz}, 6-\mathrm{CH}$ ), 131.99 (5-CH), $132.53\left(4^{\prime}-\mathrm{CH}\right), 133.39$ (d, $J=6.6 \mathrm{~Hz}, 3 \mathrm{C}$, 4-CH and $3^{\prime}-\mathrm{CH}$ ), 134.07 (br s, 4C, $2^{\prime}-$ and $3^{\prime \prime}-\mathrm{CH}$ ), 165.49 (d, $J=7.8 \mathrm{~Hz}, \mathrm{~N}=\mathrm{C}$ ), and the signals of BARF. $-{ }^{31} \mathrm{P}$ NMR $\left(\mathrm{CDCl}_{3}, 161 \mathrm{MHz}\right): \delta=+21.8$. $\delta$ HRMS ESI/FT-ICR: isotope cluster $658-662$, found (calcd.): $658.1974,51 \%$ (658.1984, 60\%); 659.2018, $17 \% \quad(659.2017,20 \%)$; $660.2012, \quad 100 \% \quad(660.2007,100 \%) ; 661.2029, \quad 32 \%$ (661.2041, $34 \%) ; 662.2083,2 \%(662.2074,5 \%)$.

\section{((3aR,8bS)-2-(2-(Diphenylphosphino)phenyl)-4,4-}

dimethyl-4,8b-dihydro-3aH-indeno[2,1-d]oxazole $)-\left(\eta^{4}-1,5\right.$ cyclooctadiene)iridium(I) tetrakis(3,5-bis(trifluoromethyl)phenyl)borate (4h)

Diphenylphosphine (61 $\mathrm{mg}, 0.33 \mathrm{mmol})$ was dissolved in diethyl ether $(1 \mathrm{~mL})$, and $n$-BuLi (1.6 M solution in hexane, $0.21 \mathrm{~mL}, 0.33 \mathrm{mmol}$ ) was added in order to generate lithium diphenylphosphide. Then $\mathbf{2 h}$ ( $84 \mathrm{mg}, 0.3 \mathrm{mmol})$ was added. After stirring overnight the generated ligand was allowed to react with $[\operatorname{Ir}(\mathrm{COD}) \mathrm{Cl}]_{2}$ and $\mathrm{NaBARF}$ as described in the general procedure $\mathrm{A}$.

Yield: $79.6 \%$. Red crystals. Very stable on storage at r. t. even in $\mathrm{CDCl}_{3}$ solution (6 month). $-[\alpha]_{\mathrm{D}}^{21}=0(c=0.105$, $\left.\mathrm{CHCl}_{3}\right),[\alpha]_{546}^{21}=+156\left(c=0.105, \mathrm{CHCl}_{3}\right) .-{ }^{1} \mathrm{H} \mathrm{NMR}$ $\left(\mathrm{CDCl}_{3}, 600 \mathrm{MHz}\right.$, r.t.): $\delta=0.76(\mathrm{~s}, 3 \mathrm{H}, \mathrm{Me}), 1.41$ (s, $3 \mathrm{H}$,

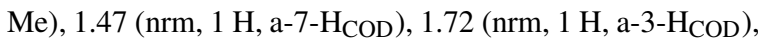

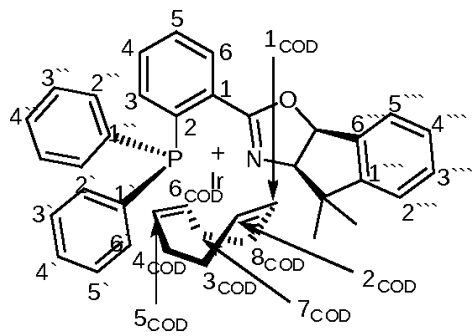

4h

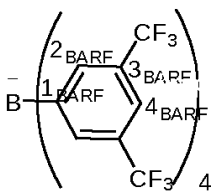

2.01 (nrm, $1 \mathrm{H}$, e-7- $\mathrm{H}_{\mathrm{COD}}$ ), 2.12 (nrm, $1 \mathrm{H}, \mathrm{e}-3-\mathrm{H}_{\mathrm{COD}}$ ), 2.42 (nrm, $\left.1 \mathrm{H}, \mathrm{a}-8-\mathrm{H}_{\mathrm{COD}}\right), 2.49$ (nrm, $\left.1 \mathrm{H}, \mathrm{a}-4-\mathrm{H}_{\mathrm{COD}}\right)$, 2.52 (nrm, $\left.1 \mathrm{H}, \mathrm{e}-8-\mathrm{H}_{\mathrm{COD}}\right), 2.63\left(\mathrm{nrm}, 1 \mathrm{H}, \mathrm{e}-4-\mathrm{H}_{\mathrm{COD}}\right)$, 3.03 (br s, $1 \mathrm{H}$, NOE with 7.10 ppm, 6- $\mathrm{H}_{\mathrm{COD}}$ ), 3.54 (br s, $1 \mathrm{H}$, NOE with $\left.7.42 \mathrm{ppm}, 5-\mathrm{H}_{\mathrm{COD}}\right), 4.69(\mathrm{~d}, J=8.5 \mathrm{~Hz}$, $1 \mathrm{H}, \mathrm{NCH}), 5.12\left(\mathrm{~m}, 1 \mathrm{H}, \mathrm{NOE}\right.$ with $\left.4.69 \mathrm{ppm}, 1-\mathrm{H}_{\mathrm{COD}}\right)$, $5.16\left(\mathrm{~m}, 1 \mathrm{H}, 2-\mathrm{H}_{\mathrm{COD}}\right), 6.17(\mathrm{~d}, J=8.5 \mathrm{~Hz}, 1 \mathrm{H}, \mathrm{OCH})$, $7.03\left(\mathrm{~d}, J=7.6 \mathrm{~Hz}, 1 \mathrm{H}, 2^{\prime \prime \prime}-\mathrm{H}\right), 7.10(\mathrm{dd}, J=11.5 \mathrm{~Hz}, J=$ $\left.7.6 \mathrm{~Hz}, 2 \mathrm{H}, 2^{\prime \prime}-\mathrm{H}\right), 7.24$ (br d, $\left.J=8.2 \mathrm{~Hz}, 1 \mathrm{H}, 3-\mathrm{H}\right), 7.28$ $\left(\mathrm{m}, 1 \mathrm{H}, 4^{\prime \prime \prime}-\mathrm{H}\right), 7.37\left(\mathrm{t}, J=7.6 \mathrm{~Hz}, 1 \mathrm{H}, 3^{\prime \prime \prime}-\mathrm{H}\right), 7.38$ (nrm, $\left.1 \mathrm{H}, 4^{\prime}-\mathrm{H}\right), 7.42$ (nrm, $5 \mathrm{H}, 2^{\prime}-, 6^{\prime}-$ and $3^{\prime \prime}-$ and $\left.4^{\prime \prime}-\mathrm{H}\right), 7.47$ $\left(\mathrm{m}, 3 \mathrm{H}, 3^{\prime}-, 5^{\prime}-\right.$ and $\left.5^{\prime \prime \prime}-\mathrm{H}\right), 7.56(\mathrm{t}, J=7.6 \mathrm{~Hz}, 1 \mathrm{H}, 4-\mathrm{H})$, $7.61(\mathrm{t}, J=7.6 \mathrm{~Hz}, 1 \mathrm{H}, 5-\mathrm{H}), 8.31$ (ddd, $J=8.2 \mathrm{~Hz}, J=$ $4.1 \mathrm{~Hz}, J=1.1 \mathrm{~Hz}, 1 \mathrm{H}, 6-\mathrm{H})$, and the signals of BARF. ${ }^{13} \mathrm{C}\left\{{ }^{1} \mathrm{H}\right\}$ NMR $\left(\mathrm{CDCl}_{3}, 150 \mathrm{MHz}\right): \delta=26.8(\mathrm{Me}), 31.2$ (Me), 25.7 (d, $\left.J=2.3 \mathrm{~Hz}, 3-\mathrm{CH}_{2 \mathrm{COD}}\right), 28.1\left(7-\mathrm{CH}_{2 \mathrm{COD}}\right)$, 32.5 (8- $\left.\mathrm{CH}_{2 \mathrm{COD}}\right), 36.2\left(4-\mathrm{CH}_{2 \mathrm{COD}}\right), 49.5\left(\mathrm{CMe}_{2}\right), 62.9$ $\left(5-\mathrm{CH}_{\mathrm{COD}}\right), 63.9\left(6-\mathrm{CH}_{\mathrm{COD}}\right), 79.09(\mathrm{NCH}), 87.8(\mathrm{OCH})$, $91.2\left(\mathrm{~d}, J=13.7 \mathrm{~Hz}, 2-\mathrm{CH}_{\mathrm{COD}}\right), 96.8(\mathrm{~d}, J=10.0 \mathrm{~Hz}$, $\left.1-\mathrm{CH}_{\mathrm{COD}}\right), 123.00\left(\mathrm{~d}, J=58.5 \mathrm{~Hz}, 1^{\prime \prime}-\mathrm{C}\right), 123.12\left(2^{\prime \prime \prime}-\mathrm{CH}\right)$, $126.30\left(5^{\prime \prime \prime}-\mathrm{CH}\right), 127.59$ (d, $\left.J=48.2 \mathrm{~Hz}, 2-\mathrm{C}\right), 128.51$ $\left(4^{\prime \prime \prime}-\mathrm{CH}\right), 128.77\left(2^{\prime}-\right.$ and 6- $\left.{ }^{\prime} \mathrm{CH}\right), 128.99(\mathrm{~d}, J=51.6 \mathrm{~Hz}$, $1^{\prime}$-C), 129.58 (d, $\left.J=13.8 \mathrm{~Hz}, 1-\mathrm{C}\right), 129.64$ (d, $J=11.5 \mathrm{~Hz}$, $\left.3^{\prime \prime}-\mathrm{CH}\right), 131.82\left(3^{\prime \prime \prime}-\mathrm{CH}\right), 132.10\left(\mathrm{~d}, J=2.3 \mathrm{~Hz}, 5^{\prime}-\mathrm{CH}\right)$, 132.44 (d, $\left.J=2.3 \mathrm{~Hz}, 3^{\prime}-\mathrm{CH}\right), 132.52$ (d, $\left.J=2.3 \mathrm{~Hz}, 5-\mathrm{CH}\right)$, 133.21 (d, $\left.J=10.3 \mathrm{~Hz}, 2^{\prime \prime}-\mathrm{CH}\right), 133.23\left(6^{\prime \prime \prime}-\mathrm{CH}\right), 133.94$ (d, $J=11.5 \mathrm{~Hz}, 6-\mathrm{CH}), 133.99\left(4^{\prime}-\mathrm{CH}\right), 134.05\left(4^{\prime \prime}-\mathrm{CH}\right), 134.11$ (d, $J=6.9 \mathrm{~Hz}, 4-\mathrm{CH}), 135.35$ (s, 3-CH), 150.87 (1'1'-CH), $163.97(\mathrm{~d}, J=5.7 \mathrm{~Hz}, \mathrm{C}=\mathrm{N})$, and the signals of BARF. ${ }^{31} \mathrm{P} \mathrm{NMR}\left(\mathrm{CDCl}_{3}, 161 \mathrm{MHz}\right): \delta=+16.5$. - HRMS ESI/FTICR: isotope cluster 746-750, found (calcd.): 746.2302, $54 \%$ (746.2297, $60 \%) ; 747.2313,22 \%$ (747.2330, $25 \%)$; $748.2293, \quad 100 \% \quad(748.2320, \quad 100 \%) ; 749.2287, \quad 43 \%$ (749.2354, $41 \%) ; 750.2255,9 \%(750.2387,8 \%)$.

\section{General procedure B for the synthesis of $\mathbf{4 g}, \mathbf{4 i}$ and $\mathbf{4 l}$}

A two-necked $10 \mathrm{~mL}$ flask was charged with liquid dicyclohexylphosphine (1i, $65 \mathrm{mg}, 0.33 \mathrm{mmol}$ ) or solid dixylylphosphine (1g, $80 \mathrm{mg}, 0.33 \mathrm{mmol})$ as described in general procedure A. Abs. MTBE $(4 \mathrm{~mL})$ was added, and the diarylphosphine was dissolved. $n$-BuLi (1.6 M solution in hexane, $0.21 \mathrm{~mL}, 0.33 \mathrm{mmol}$ ) was added at r.t., and the 
yellow (for 1g) or colorless (for 1i) mixture was stirred for $30 \mathrm{~min}$. Liquid oxazoline $2 \mathrm{c}(62 \mathrm{mg}, 0.3 \mathrm{mmol})$ was added to the reaction mixture. The mixture was refluxed for $12 \mathrm{~h}$ and cooled. At this point gas chromatography with mass-sensitive analyzer showed a conversion of $\mathbf{2 c}$ of over $80 \%$ into the ligand 3 . The mixture was evaporated in a stream of nitrogen. $[\mathrm{Ir}(\mathrm{COD}) \mathrm{Cl}]_{2}(100.8 \mathrm{mg}, 0.15 \mathrm{mmol})$ and $\mathrm{CH}_{2} \mathrm{Cl}_{2}(3 \mathrm{~mL})$ were added to the residue, and the mixture was refluxed for $4 \mathrm{~h}$. After cooling the anion exchange (to $\mathrm{BARF}$ or $\mathrm{PF}_{6}$ ) was performed according to the general procedure $\mathrm{A}$.

((4S)-2-(2-(Bis(2,6-dimethylphenyl)phosphino)phenyl)-4isopropyl-4,5-dihydrooxazole)-( $\eta^{4}-1,5$-cyclooctadiene)iridium(I) tetrakis(3,5-bis(trifluoromethyl)phenyl)borate (4g)

Yield: $66.9 \%$. This complex was catalytically active in stilbene hydrogenation, but impure. It could not be purified even by gradient column chromatography (hexanedichloromethane). Yellow crystals, unstable even in crystalline state. Should be stored at $-20{ }^{\circ} \mathrm{C} .-[\alpha]_{\mathrm{D}}^{21}=-19(c=$ $\left.0.12, \mathrm{CHCl}_{3}\right),[\alpha]_{546}^{21}=-48\left(c=0.12, \mathrm{CHCl}_{3}\right) .-{ }^{1} \mathrm{H} \mathrm{NMR}$ $\left(\mathrm{CDCl}_{3}, 600 \mathrm{MHz}, \mathrm{r} . \mathrm{t}.\right): \delta=0.48(\mathrm{~d}, J=6.7 \mathrm{~Hz}, 3 \mathrm{H}$, $\left.\mathrm{Me}_{\mathrm{iPr}}\right), 1.01\left(\mathrm{~d}, J=6.7 \mathrm{~Hz}, 3 \mathrm{H}, \mathrm{Me}_{\mathrm{iPr}}\right), 1.85(\mathrm{~s}, 3 \mathrm{H}$, 6"-Me), 2.00 (s, $3 \mathrm{H}, 2^{\prime \prime}-\mathrm{Me}$ ), 2.22 (s, $3 \mathrm{H}, 2^{\prime}-\mathrm{Me}$ ), 2.50 $(\mathrm{m}, 1 \mathrm{H}, \mathrm{CHMe}), 3.19\left(\mathrm{~m}, 1 \mathrm{H}, 5-\mathrm{H}_{\mathrm{COD}}\right), 3.29(\mathrm{~m}, 1 \mathrm{H}$, 6- $\mathrm{H}_{\mathrm{COD}}$ ), 4.40 (br d, $J=8.1 \mathrm{~Hz}, 2 \mathrm{H}, \mathrm{OCH}_{2}$ ), 4.63 (br $\mathrm{td}, J=8.1 \mathrm{~Hz}, J=2.5 \mathrm{~Hz}, 1 \mathrm{H}, \mathrm{NCH}), 4.70(\mathrm{~m}, \mathrm{NOE}$ with $3.29 \mathrm{ppm}$, with $\left.1.76 \mathrm{ppm}, 1 \mathrm{H}, 2-\mathrm{H}_{\mathrm{COD}}\right), 5.24$ (m, $1 \mathrm{H}$, NOE with $\left.2.5 \mathrm{ppm}, 4.63 \mathrm{ppm}, 1-\mathrm{H}_{\mathrm{COD}}\right), 6.86$ (br s, $\left.1 \mathrm{H}, 4^{\prime}-\mathrm{H}\right), 7.05$ (nrm, $2 \mathrm{H}, 3^{\prime}-$ and $\left.5^{\prime}-\mathrm{H}\right), 7.15$ (nrm, $2 \mathrm{H}, 3^{\prime \prime}-$ and $\left.5^{\prime \prime}-\mathrm{H}\right), 7.37\left(\mathrm{nrm}, 1 \mathrm{H}, 4^{\prime \prime}-\mathrm{H}\right), 7.55(\mathrm{t}, J=$ $7.5 \mathrm{~Hz}, 1 \mathrm{H}, 5-\mathrm{H}), 7.66(\mathrm{t}, J=7.5 \mathrm{~Hz}, 1 \mathrm{H}, 4-\mathrm{H}), 8.05$ $(\mathrm{dd}, J=10.3 \mathrm{~Hz}, J=7.5 \mathrm{~Hz}, 1 \mathrm{H}, 3-\mathrm{H}), 8.27(\mathrm{t}, J=$ $7.5 \mathrm{~Hz}, 1 \mathrm{H}, 6-\mathrm{H})$, and the signals of BARF, $\mathrm{CH}_{2 \mathrm{COD}}$ and $6^{\prime}$-Me are not distinguishable, since the compound is not pure. ${ }^{13} \mathrm{C}\left\{{ }^{1} \mathrm{H}\right\}$ NMR $\left(\mathrm{CDCl}_{3}, 150 \mathrm{MHz}\right): \delta=7.53\left(6^{\prime}-\right.$ $\mathrm{Me}), 13.78\left(\mathrm{Me}_{\mathrm{iPr}}\right), 19.01\left(\mathrm{Me}_{\mathrm{iPr}}\right), 22.78\left(2 \mathrm{C}, 2^{\prime}-\mathrm{Me}\right.$ and $\left.2^{\prime \prime}-\mathrm{Me}\right), 26.73$ (6"-Me), $29.94\left(\mathrm{CHMe}_{2}\right), 44.66$ (6-CH $\left.\mathrm{CHD}_{\mathrm{COD}}\right)$, $66.90\left(5-\mathrm{CH}_{\mathrm{COD}}\right), 67.04\left(\mathrm{OCH}_{2}\right), 79.38(\mathrm{~d}, J=23.8 \mathrm{~Hz}$, 1-CH $\mathrm{COD}), 81.75(\mathrm{NCH}), 103.05\left(\mathrm{~s}, 2-\mathrm{CH}_{\mathrm{COD}}\right), 123.42$ (d, $\left.J=16.5 \mathrm{~Hz}, 3^{\prime}-\mathrm{CH}\right), 126.00(\mathrm{~d}, J=12.8 \mathrm{~Hz}, 1-\mathrm{C}), 126.28$ (d, $\left.J=56.82 \mathrm{~Hz}, 1^{\prime \prime}-\mathrm{C}\right), 129.76$ (d, $\left.J=47.7 \mathrm{~Hz}, 2-\mathrm{C}\right), 130.32$ (d, $\left.J=7.3 \mathrm{~Hz}, 4^{\prime}-\mathrm{CH}\right), 130.51$ (d, $\left.J=88.0 \mathrm{~Hz}, 1^{\prime}-\mathrm{C}\right), 130.74$ (d, $\left.J=7.3 \mathrm{~Hz}, 3^{\prime \prime}-\mathrm{CH}\right), 130.76\left(\mathrm{~d}, J=12.8 \mathrm{~Hz}, 6^{\prime}-C \mathrm{Me}\right)$, 131.14 (d, $\left.J=7.3 \mathrm{~Hz}, 5^{\prime \prime}-\mathrm{CH}\right), 131.48\left(\mathrm{~s}, 4^{\prime \prime}-\mathrm{CH}\right), 131.68$ (s, 5'-CH), $131.82(5-\mathrm{CH}), 131.98(\mathrm{~d}, J=7.3 \mathrm{~Hz}, 4-\mathrm{CH})$, 134.85 (d, $J=7.3 \mathrm{~Hz}, 6-\mathrm{CH}), 135.53$ (s, 3-CH), 140.35 (d, $\left.J=9.2 \mathrm{~Hz}, 2^{\prime \prime}-C \mathrm{Me}\right), 141.27\left(\mathrm{~d}, J=9.2 \mathrm{~Hz}, 6^{\prime \prime}-C \mathrm{Me}\right), 141.45$ (d, $\left.J=1.6 \mathrm{~Hz}, 2^{\prime}-C \mathrm{Me}\right), 163.8(\mathrm{~d}, J=5.5 \mathrm{~Hz}, \mathrm{~N}=\mathrm{C})$, and the signals of BARF, $\mathrm{CH}_{2 \mathrm{COD}}$ are not distinguishable, since the compound is not pure. $-{ }^{31} \mathrm{P}$ NMR $\left(\mathrm{CDCl}_{3}, 161 \mathrm{MHz}\right)$ : $\delta=+20.8$. - HRMS ESI/FT-ICR: isotope cluster 728-732, found (calcd.): 728.2704, $78 \%$ (728.2766, $60 \%)$; 729.2763 ,
$28 \%$ (729.2800, $23 \%) ; 730.2783,100 \%$ (730.2790, $100 \%)$; $731.2773,36 \%$ (731.2823, $39 \%) ; 732.2912,5 \%$ (732.2857, $7 \%)$.

((4S)-2-(2-(Dicyclohexylphosphino)phenyl)-4-isopropyl4,5-dihydrooxazole)-( $\eta^{4}$-1,5-cyclooctadiene)iridium(I) tetrakis(3,5-bis(trifluoromethyl)phenyl)borate (4i)

Yield: $70 \%$. This complex was catalytically active in stilbene hydrogenation, but contaminated with dicyclohexylphosphine oxide, and the contaminant could not be removed even by gradient column chromatography (hexanedichloromethane). The synthesis of analytically pure $4 \mathbf{i}$ is described below.

((4S)-2-(2-(Dicyclohexylphosphino)phenyl)-4-isopropyl4,5-dihydrooxazole)-( $\eta^{4}$-1,5-cyclooctadiene)iridium(I) hexafluorophosphate (4l)

Yield: $68 \%$. Red crystals. Very unstable on storage even as crystals at r.t. (stable for $1 \mathrm{~d}$ ). Should be stored at $-20{ }^{\circ} \mathrm{C} .-[\alpha]_{\mathrm{D}}^{19}=-136\left(c=0.11, \mathrm{CHCl}_{3}\right) .-{ }^{1} \mathrm{H} \mathrm{NMR}$ $\left(\mathrm{CDCl}_{3}, 600 \mathrm{MHz}\right.$, r. t. $): \delta=0.80(\mathrm{~d}, J=6.6 \mathrm{~Hz}, 3 \mathrm{H}, \mathrm{Me})$, $1.08(\mathrm{~d}, J=6.9 \mathrm{~Hz}, 3 \mathrm{H}, \mathrm{Me}), 1.15-1.4(\mathrm{nrm}, 8 \mathrm{H}, \mathrm{Cy})$, $1.4-1.5$ (nrm, $2 \mathrm{H}, \mathrm{Cy}), 1.70-1.95$ (nrm, $10 \mathrm{H}, \mathrm{Cy}), 1.61$ (nrm, 1 H, a-4-H $\mathrm{H}_{\mathrm{COD}}$ ), 1.66 (nrm, $1 \mathrm{H}, \mathrm{a}-8-\mathrm{H}_{\mathrm{COD}}$ ), 2.07 (nrm, $2 \mathrm{H}, \mathrm{CHMe}$ and e-8-H $\left.\mathrm{HOD}_{\mathrm{COD}}\right), 2.13$ (nrm, $2 \mathrm{H}, \mathrm{e}-4-\mathrm{H}_{\mathrm{COD}}$ and $\left.1^{\prime}-\mathrm{H}\right), 2.29$ (nrm, $\left.1 \mathrm{H}, \mathrm{a}-3-\mathrm{H}_{\mathrm{COD}}\right), 2.49$ (nrm, $4 \mathrm{H}, \mathrm{e}-3-\mathrm{H}_{\mathrm{COD}}$, 7- $\mathrm{H}_{\mathrm{COD}}$ and $\left.1^{\prime \prime}-\mathrm{H}\right), 3.69$ (br s, $1 \mathrm{H}, 5-\mathrm{H}_{\mathrm{COD}}$ ), 4.15 (br s, $\left.1 \mathrm{H}, 6-\mathrm{H}_{\mathrm{COD}}\right), 4.32(\mathrm{~m}, 1 \mathrm{H}, \mathrm{NCH}), 4.62(\mathrm{~d}, J=5.9 \mathrm{~Hz}$, $2 \mathrm{H}, \mathrm{OCH}_{2}$ ), 4.74 (m, NOE with 2.07, 4.32 and $4.62 \mathrm{ppm}$, $1 \mathrm{H}, 1-\mathrm{H}_{\mathrm{COD}}$ ), 5.13 (br s, NOE with 4.32 and $4.62 \mathrm{ppm}, 1 \mathrm{H}$, 2- $\mathrm{H}_{\mathrm{COD}}$ ), 7.67 (pseudo-t, $\left.J=7.8 \mathrm{~Hz}, 1 \mathrm{H}, 5-\mathrm{H}\right), 7.78$ (m, $2 \mathrm{H}$, 3- and 4-H), 8.31 (dd, $J=7.9 \mathrm{~Hz}, J=2.9 \mathrm{~Hz}, 1 \mathrm{H}, 6-\mathrm{H})$. ${ }^{13} \mathrm{C}\left\{{ }^{1} \mathrm{H}\right\}$ NMR $\left(\mathrm{CDCl}_{3}, 150 \mathrm{MHz}\right): \delta=14.84(\mathrm{Me}), 19.26$ (Me), 25.87 (Cy), 26.03 (Cy), 26.09 (8- $\left.\mathrm{CH}_{2 \mathrm{COD}}\right), 26.94$ (d, $J=8.0 \mathrm{~Hz}, \mathrm{Cy}), 27.02$ (d, $J=9.2 \mathrm{~Hz}, \mathrm{Cy}), 27.13$ (d, $J=$ $11.5 \mathrm{~Hz}, \mathrm{Cy}), 27.32$ (d, $J=9.2 \mathrm{~Hz}, \mathrm{Cy}), 28.12$ (d, $J=3.4 \mathrm{~Hz}$, Cy), 29.11 (Cy), 29.44 (4-CH2COD), 29.98 (Cy), 30.65 (Cy), $31.65\left(3-\mathrm{CH}_{2 \mathrm{COD}}\right), 32.09$ (d, $\left.J=27.5 \mathrm{~Hz}, 1^{\prime \prime}-\mathrm{CH}\right), 32.96$ $\left(\mathrm{CHMe}_{2}\right), 36.15\left(7-\mathrm{CH}_{2} \mathrm{COD}\right), 41.95\left(\mathrm{~d}, J=26.4 \mathrm{~Hz}, 1^{\prime}-\mathrm{CH}\right)$, $59.86\left(5-\mathrm{CH}_{\mathrm{COD}}\right), 61.92\left(6-\mathrm{CH}_{\mathrm{COD}}\right), 68.20\left(\mathrm{OCH}_{2}\right), 70.19$ $(\mathrm{NCH}), 89.90\left(\mathrm{~d}, J=11.5 \mathrm{~Hz}, 1-\mathrm{CH}_{\mathrm{COD}}\right), 95.46(\mathrm{~d}, J=$ $\left.11.5 \mathrm{~Hz}, 2-\mathrm{CH}_{\mathrm{COD}}\right), 126.80$ (d, $\left.J=35.6 \mathrm{~Hz}, 2-\mathrm{C}\right), 129.45$ (d, $J=9.2 \mathrm{~Hz}, 1-\mathrm{C}), 131.74$ (d, $J=2.3 \mathrm{~Hz}, 5-\mathrm{CH}), 132.43$ (d, $J=1.2 \mathrm{~Hz}, 3-\mathrm{CH}), 133.87$ (d, $J=5.7 \mathrm{~Hz}, 4-\mathrm{CH}), 134.07$ (d, $J=8.0 \mathrm{~Hz}, 6-\mathrm{CH}), 164.34(\mathrm{~d}, J=5.7 \mathrm{~Hz}, \mathrm{~N}=\mathrm{C}) .-{ }^{31} \mathrm{P} \mathrm{NMR}$ $\left(\mathrm{CDCl}_{3}, 161 \mathrm{MHz}\right): \delta=+10.1$ (ligand), -143.7 (sep, $J=$ $\left.714 \mathrm{~Hz}, \mathrm{PF}_{6}\right) .-{ }^{19} \mathrm{~F} \mathrm{NMR}\left(\mathrm{CDCl}_{3}, 376 \mathrm{MHz}\right): \delta=-73.6(\mathrm{~d}$, $J=714 \mathrm{~Hz}$ ). - HRMS ESI/FT-ICR: isotope cluster $684-688$, found (calcd.): 684.3051, $54 \%(684.3079,60 \%) ; 685.3070$, $17 \%$ (685.3113, $21 \%) ; 686.3089,100 \%$ (686.3103, $100 \%)$; 687.3071, $33 \%(687.3136,35 \%) ; 688.3137,5 \%$ (688.3170, $6 \%)$. 
((4S)-2-(2-(Dicyclohexylphosphino)phenyl)-4-isopropyl4,5-dihydrooxazole)-( $\eta^{4}$-1,5-cyclooctadiene)iridium(I) tetrakis(3,5-bis(trifluoromethyl)phenyl)borate (4i) from $\mathbf{4 l}$

$4 \mathbf{l}$ (50 mg, $0.06 \mathrm{mmol}$ ) and NaBARF (54 mg, $0.061 \mathrm{mmol}$ ) were dissolved in $\mathrm{CH}_{2} \mathrm{Cl}_{2}(5 \mathrm{~mL})$. The anion exchange was monitored by TLC on silica gel eluting with $\mathrm{CH}_{2} \mathrm{Cl}_{2}$. $R_{\mathrm{f}}$ of $4 \mathrm{I}$ is 0 , that of $4 \mathbf{i}$ is 0.9 . Within $2 \mathrm{~h}$ the mixture was adsorbed on silica gel and chromatographed on silica gel $(10 \mathrm{~g})$ according to the general procedure A. Yield: $71 \%$. Red crystals. Stable on storage in crystalline form at r.t. for at least 1 week. Nevertheless, it should be stored at $-20{ }^{\circ} \mathrm{C} .-[\alpha]_{\mathrm{D}}^{19}=-48(c=$ $\left.0.135, \mathrm{CHCl}_{3}\right) .-{ }^{1} \mathrm{H} \mathrm{NMR}\left(\mathrm{CDCl}_{3}, 600 \mathrm{MHz}\right.$, r. t. $): \delta=0.77$ $(\mathrm{d}, J=6.4 \mathrm{~Hz}, 3 \mathrm{H}, \mathrm{Me}), 1.00(\mathrm{~d}, J=7.0 \mathrm{~Hz}, 3 \mathrm{H}, \mathrm{Me})$, 1.19 - 1.35 (nrm, 8 H, Cy), 1.37 - 1.50 (nrm, 2 H, Cy), 1.661.93 (nrm, $10 \mathrm{H}, \mathrm{Cy}), 1.61$ (nrm, $2 \mathrm{H}, \mathrm{a}-4-$ and a-8-H $\mathrm{H}_{\mathrm{COD}}$ ), 2.01 (nrm, $\left.1 \mathrm{H}, \mathrm{e}-8-\mathrm{H}_{\mathrm{COD}}\right), 2.07$ (m, $\left.1 \mathrm{H}, \mathrm{CHMe} 2\right), 2.14$ (nrm, $\left.1 \mathrm{H}, \mathrm{e}-4-\mathrm{H}_{\mathrm{COD}}\right), 2.07$ (nrm, $\left.1 \mathrm{H}, \mathrm{a}-7-\mathrm{H}_{\mathrm{COD}}\right), 2.22$ (nrm, $\left.1 \mathrm{H}, 1^{\prime}-\mathrm{H}\right), 2.23\left(\mathrm{nrm}, 1 \mathrm{H}, \mathrm{a}-3-\mathrm{H}_{\mathrm{COD}}\right), 2.38(\mathrm{nmr}$, $\left.1 \mathrm{H}, \mathrm{e}-3-\mathrm{H}_{\mathrm{COD}}\right), 2.46$ (nrm, $\left.1 \mathrm{H}, \mathrm{e}-7-\mathrm{H}_{\mathrm{COD}}\right), 2.47$ (nrm, $\left.1 \mathrm{H}, 1^{\prime \prime}-\mathrm{H}\right), 3.72$ (br s, 5-CH $\left.\mathrm{COD}\right), 4.16(\mathrm{dt}, J=8.8 \mathrm{~Hz}$, $J=2.9 \mathrm{~Hz}, 1 \mathrm{H}, \mathrm{NCH}), 4.19$ (br s, $\left.1 \mathrm{H}, 6-\mathrm{CH}_{\mathrm{COD}}\right), 4.32$ (t, $\left.J=9.4 \mathrm{~Hz}, 1 \mathrm{H}, \mathrm{OCH}_{2}\right), 4.55(\mathrm{dd}, J=9.4 \mathrm{~Hz}, J=2.9 \mathrm{~Hz}$, $\left.1 \mathrm{H}, \mathrm{OCH}_{2}\right), 4.66$ (m, NOE with 4.16, 2.07, $0.77 \mathrm{ppm}, 1 \mathrm{H}$, 1- $\mathrm{H}_{\mathrm{COD}}$ ), 4.86 (br s, NOE with $4.16 \mathrm{ppm}, 1 \mathrm{H}, 2-\mathrm{H}_{\mathrm{COD}}$ ), $7.55(\mathrm{~m}, 1 \mathrm{H}, 5-\mathrm{H}), 7.66(\mathrm{t}, J=7.6 \mathrm{~Hz}, 1 \mathrm{H}, 4-\mathrm{H}), 7.74$ (br $\mathrm{s}$ and $\mathrm{d}, J=8.8 \mathrm{~Hz}, 9 \mathrm{H}, 2-\mathrm{H}_{\mathrm{BARF}}$ and $\left.3-\mathrm{H}\right), 8.21(\mathrm{dd}, J=$ $10.6 \mathrm{~Hz}, J=2.4 \mathrm{~Hz}, 1 \mathrm{H}, 6-\mathrm{H})$, and the signals of BARF. ${ }^{13} \mathrm{C}\left\{{ }^{1} \mathrm{H}\right\} \mathrm{NMR}\left(\mathrm{CDCl}_{3}, 150 \mathrm{MHz}\right): \delta=14.53(\mathrm{Me}), 19.16$ (Me), 25.76 (Cy), 26.00 (2C, Cy and 8- $\mathrm{CH}_{2 \mathrm{COD}}$ ), 26.91 (d, $J=9.2 \mathrm{~Hz}, \mathrm{Cy}), 26.99$ (d, $J=9.2 \mathrm{~Hz}, \mathrm{Cy}), 27.12(\mathrm{~d}, J=$ $11.5 \mathrm{~Hz}, \mathrm{Cy}), 27.37$ (d, $J=10.3 \mathrm{~Hz}, \mathrm{Cy}), 28.23$ (d, $J=2.3 \mathrm{~Hz}$, Cy), 29.18 (Cy), 29.43 (4- $\left.\mathrm{CH}_{2 \mathrm{COD}}\right), 30.18$ (Cy), 30.68 (Cy), $31.57\left(3-\mathrm{CH}_{2 \mathrm{COD}}\right), 32.20$ (d, $\left.J=28.7 \mathrm{~Hz}, 1^{\prime \prime}-\mathrm{C}\right), 32.87$ $\left(C \mathrm{HMe}_{2}\right), 36.04\left(\mathrm{~d}, J=3.5 \mathrm{~Hz}, 7-\mathrm{CH}_{2 \mathrm{COD}}\right), 42.18(\mathrm{~d}, J=$ $\left.27.5 \mathrm{~Hz}, 1^{\prime}-\mathrm{C}\right), 60.82\left(5-\mathrm{CH}_{\mathrm{COD}}\right), 62.92\left(6-\mathrm{CH}_{\mathrm{COD}}\right), 67.87$ $\left(\mathrm{OCH}_{2}\right), 70.27(\mathrm{NCH}), 89.43\left(\mathrm{~d}, J=13.8 \mathrm{~Hz}, 1-\mathrm{CH}_{\mathrm{COD}}\right)$, $94.14\left(\mathrm{~d}, J=10.3 \mathrm{~Hz}, 2-\mathrm{CH}_{\mathrm{COD}}\right), 127.04(\mathrm{~d}, J=35.6 \mathrm{~Hz}$, 2-C), 129.16 (d, $J=11.5 \mathrm{~Hz}, 1-\mathrm{C}), 131.84(5-\mathrm{CH}), 132.38$ (s, 3-CH), 134.03 (d, $J=6.9 \mathrm{~Hz}, 6-\mathrm{CH}), 133.94(\mathrm{~d}, J=$ $5.7 \mathrm{~Hz}, 4-\mathrm{CH}), 164.4(\mathrm{~d}, J=5.8 \mathrm{~Hz}, \mathrm{~N}=\mathrm{C})$, and the signals of BARF. $-{ }^{31} \mathrm{P}$ NMR $\left(\mathrm{CDCl}_{3}, 161 \mathrm{MHz}\right): \delta=$ +10.4. - HRMS ESI/FT-ICR: isotope cluster 684-688, found (calcd.): 684.3045, $54 \%(684.3079,60 \%) ; 685.3143$, $19 \%$ (685.3113, $21 \%)$; 686.3098, $100 \%$ (686.3103, $100 \%)$; 687.3043, $34 \%(687.3136,35 \%) ; 688.3145,8 \%$ (688.3170, $6 \%)$.

(1S)-((4S)-2-(2-(Diphenylphosphino)phenyl)-4,5-dihydrooxazol-4-yl)(phenyl)methanol-( $\eta^{4}-1,5$-cyclooctadiene)iridium(I) tetrakis(3,5-bis(trifluoromethyl)phenyl)borate (4m)

$2 \mathrm{~m}(41.3 \mathrm{mg}, 0.152 \mathrm{mmol})$ was dissolved in $5 \mathrm{~mL}$ of abs. $\mathrm{Et}_{2} \mathrm{O}$. To this solution $\mathrm{KPPh}_{2}(0.5 \mathrm{~N}$ solution in THF,

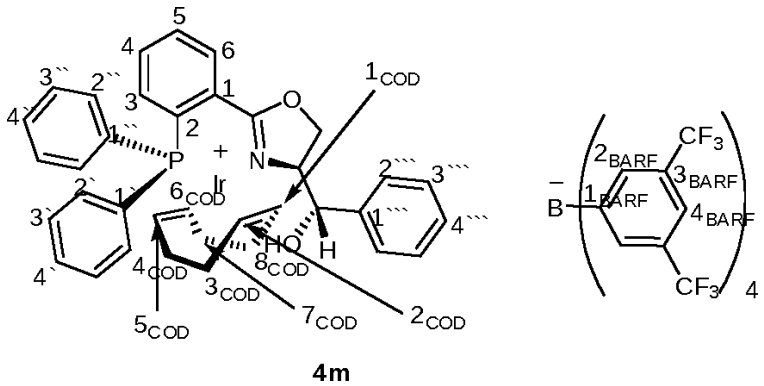

Aldrich, $0.64 \mathrm{~mL}, 0.32 \mathrm{mmol}$ ) was added at r.t. The mixture was stirred overnight at r.t. Degassed water (a few drops) was added, and all volatiles (including diphenylphosphine) were removed in vacuo $\left(10^{-2} \mathrm{mbar}\right)$ with heating $\left(60{ }^{\circ} \mathrm{C}\right)$. The residue was redissolved in abs. $\mathrm{CH}_{2} \mathrm{Cl}_{2}(5 \mathrm{~mL})$. A ${ }^{31} \mathrm{P}$ NMR spectrum of this solution showed one signal at $\delta=-6 \mathrm{ppm}$ (consistent with ref. [29]). [ $\operatorname{Ir}(\mathrm{COD}) \mathrm{Cl}]_{2}$ (50 mg, $0.0744 \mathrm{mmol}$ ) was added to this solution, which was stirred at r.t. for $2 \mathrm{~h}$ (refluxing leads to decomposition of the target complex). A ${ }^{31} \mathrm{P}$ NMR spectrum of this solution showed one singlet at $\delta=+20 \mathrm{ppm}$. From this point work was continued in air. NaBARF (135 mg, $0.152 \mathrm{mmol})$ was added, and the mixture was stirred for $2 \mathrm{~h}$. The mixture was adsorbed on $1 \mathrm{~g}$ of silica gel, and column chromatography was performed on $20 \mathrm{~g}$ of silica gel according to the general procedure $\mathrm{A}$ with the mixture $\mathrm{CH}_{2} \mathrm{Cl}_{2}$-hexane $(2: 1)$. The first spot represented some by-products, whereas the more polar second spot represented the title compound. Yield: $34 \%$. Red crystals. Very unstable even in crystalline state at r.t., should be stored at $-20{ }^{\circ} \mathrm{C}$ or below. In $\mathrm{CDCl}_{3}$ solution, decomposition begins within $1 \mathrm{~h} .-[\alpha]_{\mathrm{D}}^{25}=-113$ $\left(c=0.11, \mathrm{CHCl}_{3}\right) .-{ }^{1} \mathrm{H} \mathrm{NMR}\left(\mathrm{CDCl}_{3}, 600 \mathrm{MHz}\right.$, r.t. $): \delta=$ 1.44 (nrm, $\left.1 \mathrm{H}, \mathrm{a}-4-\mathrm{H}_{\mathrm{COD}}\right), 1.57$ (nrm, $\left.1 \mathrm{H}, \mathrm{a}-8-\mathrm{H}_{\mathrm{COD}}\right), 2.01$ (nrm, $1 \mathrm{H}, \mathrm{e}-8-\mathrm{H}_{\mathrm{COD}}$ ), 2.05 (nrm, $1 \mathrm{H}, \mathrm{e}-4-\mathrm{H}_{\mathrm{COD}}$ ), 2.41 (nrm, $\left.1 \mathrm{H}, \mathrm{a}-7-\mathrm{H}_{\mathrm{COD}}\right), 2.47\left(\mathrm{nrm}, 1 \mathrm{H}, \mathrm{a}-3-\mathrm{H}_{\mathrm{COD}}\right), 2.52(\mathrm{nrm}, 1 \mathrm{H}$, e-3- $\left.\mathrm{H}_{\mathrm{COD}}\right), 2.53\left(\mathrm{nrm}, 1 \mathrm{H}, \mathrm{e}-7-\mathrm{H}_{\mathrm{COD}}\right), 3.21$ (s, $1 \mathrm{H}, \mathrm{NOE}$ with 7.14 ppm, 5- $\left.\mathrm{H}_{\mathrm{COD}}\right), 3.38$ (s, 1 H, 6- $\left.\mathrm{H}_{\mathrm{COD}}\right), 3.72$ (m, $\left.2 \mathrm{H}, \mathrm{OCH}_{2}\right), 4.13$ (m, $\left.1 \mathrm{H}, \mathrm{NCH}\right), 4.68$ (br s, $1 \mathrm{H}, 2-\mathrm{H}_{\mathrm{COD}}$ ), $4.82\left(\mathrm{~s}, 1 \mathrm{H}\right.$, NOE with $\left.4.13 \mathrm{ppm}, 1-\mathrm{H}_{\mathrm{COD}}\right), 5.68(\mathrm{~d}, J=$ $3.5 \mathrm{~Hz}, \mathrm{CHOH}$ ), 7.14 (br s, $2 \mathrm{H}, 2^{\prime}-\mathrm{H}$ ), 7.26 (s under signal of $\left.\mathrm{CHCl}_{3}, 2^{\prime \prime \prime}-\mathrm{H}\right), 7.44(\mathrm{nrm}, 1 \mathrm{H}, 3-\mathrm{H}), 7.46(\mathrm{nrm}, 1 \mathrm{H}$, $\left.4^{\prime \prime \prime}-\mathrm{H}\right), 7.47$ (nrm, $3 \mathrm{H}, 4^{\prime}-$ and $\left.3^{\prime \prime \prime}-\mathrm{H}\right), 7.49$ (nrm, $\left.2 \mathrm{H}, 3^{\prime}-\mathrm{H}\right)$, 7.57 (nrm, $\left.1 \mathrm{H}, 4^{\prime \prime}-\mathrm{H}\right), 7.58$ (nrm, $\left.2 \mathrm{H}, 3^{\prime \prime}-\mathrm{H}\right), 7.65$ (nrm, $\left.2 \mathrm{H}, 2^{\prime \prime}-\mathrm{H}\right), 7.66$ (nrm, $\left.1 \mathrm{H}, 4-\mathrm{H}\right), 7.70$ (nrm, $\left.1 \mathrm{H}, 5-\mathrm{H}\right), 8.31$ $(\mathrm{m}, 1 \mathrm{H}, 6-\mathrm{H})$, and the signals of BARF, OH-exchanged. ${ }^{13} \mathrm{C}\left\{{ }^{1} \mathrm{H}\right\} \mathrm{NMR}\left(\mathrm{CDCl}_{3}, 150 \mathrm{MHz}\right): \delta=26.37\left(8-\mathrm{CH}_{2 \mathrm{COD}}\right)$, 28.52 (4- $\mathrm{CH}_{2 \mathrm{COD}}$ ), 32.24 (7- $\mathrm{CH}_{2 \mathrm{COD}}$ ), 36.15 (3- $\mathrm{CH}_{2 \mathrm{COD}}$ ), $64.12\left(5-\mathrm{CH}_{\mathrm{COD}}\right), 64.42\left(6-\mathrm{CH}_{\mathrm{COD}}\right), 64.54\left(\mathrm{OCH}_{2}\right), 74.27$ $(\mathrm{NCH}), 83.33(\mathrm{CHOH}), 93.76\left(\mathrm{~d}, J=13.8 \mathrm{~Hz}, 1-\mathrm{CH}_{\mathrm{COD}}\right)$, $97.08\left(\mathrm{~d}, J=11.5 \mathrm{~Hz}, 2-\mathrm{CH}_{\mathrm{COD}}\right), 121.20(\mathrm{~d}, J=58.5 \mathrm{~Hz}$, $\left.1^{\prime}-\mathrm{C}\right), 124.85\left(2^{\prime \prime \prime}-\mathrm{CH}\right), 128.51$ (d, $\left.J=48.2 \mathrm{~Hz}, 2-\mathrm{C}\right), 128.63$ (d, $J=12.6 \mathrm{~Hz}, 1-\mathrm{C}), 129.15$ (d, $\left.J=11.5 \mathrm{~Hz}, 3^{\prime}-\mathrm{CH}\right), 129.75$ 
$\left(3^{\prime \prime \prime}-\mathrm{CH}\right), 129.82\left(\mathrm{~d}, J=53.9 \mathrm{~Hz}, 1^{\prime \prime}-\mathrm{C}\right), 130.04\left(3^{\prime \prime}-\mathrm{CH}\right)$, $130.18\left(4^{\prime \prime \prime}-\mathrm{CH}\right), 130.40\left(4^{\prime}-\mathrm{CH}\right), 132.46\left(4^{\prime \prime}-\mathrm{CH}\right), 132.59$ (5-CH), 132.99 (d, $\left.J=14.5 \mathrm{~Hz}, 2^{\prime}-\mathrm{CH}\right), 133.84$ (s, 3-CH), $133.86(\mathrm{~d}, J=8.0 \mathrm{~Hz}, 6-\mathrm{CH}), 134.41(\mathrm{~d}, J=12.6 \mathrm{~Hz}, 3 \mathrm{C}, 4-$ and $\left.2^{\prime \prime}-\mathrm{CH}\right), 136.93\left(1^{\prime \prime \prime}-\mathrm{C}\right), 164.67(\mathrm{~d}, J=5.7 \mathrm{~Hz}, \mathrm{~N}=\mathrm{C})$, and the signals of BARF. $-{ }^{31} \mathrm{P}$ NMR $\left(\mathrm{CDCl}_{3}, 161 \mathrm{MHz}\right)$ : $\delta=+16.9$. - HRMS ESI/FT-ICR: isotope cluster 736-740, found (calcd.): 736.2111, $54 \%$ (736.2090, $60 \%)$; 737.2136, $23 \%(737.2123,23 \%) ; 738.2131,100 \%(738.2113,100 \%)$; $739.2160,36 \%$ (739.2146, $39 \%), 740.2230,5 \%$ (740.2180, $7 \%)$.

((4S)-2-(2-(Diphenylphosphino)phenyl)-4-isopropyl4,5-dihydrooxazole)-( $\eta^{4}-1,5$-cyclooctadiene)rhodium(I) tetrakis(3,5-bis(trifluoromethyl)phenyl)borate (5)

According to the general procedure A, with $[\mathrm{Rh}(\mathrm{COD}) \mathrm{Cl}]_{2}$. Yield: $86 \%$. Yellow crystals. Stable in $\mathrm{CDCl}_{3}$ solution at $-20{ }^{\circ} \mathrm{C}$ for at least 2 weeks. Should be stored at $-20{ }^{\circ} \mathrm{C}$ in crystalline form. $-[\alpha]_{\mathrm{D}}^{21}=-41(c=$ 0.11, $\left.\mathrm{CHCl}_{3}\right) .-{ }^{1} \mathrm{H} \mathrm{NMR}\left(\mathrm{CDCl}_{3}, 600 \mathrm{MHz}\right.$, r.t.): $\delta=$ $-0.15(\mathrm{~d}, J=6.6 \mathrm{~Hz}, 3 \mathrm{H}, \mathrm{Me}), 0.80(\mathrm{~d}, J=7.0 \mathrm{~Hz}, 3 \mathrm{H}$, Me), 1.85 (nrm, 1 H, a-4-H $\mathrm{COD}_{\text {) }}, 1.95$ (nrm, $2 \mathrm{H}, \mathrm{CHMe}$ and a-8- $\mathrm{H}_{\mathrm{COD}}$ ), 2.13 (nrm, $\left.1 \mathrm{H}, \mathrm{e}-4-\mathrm{H}_{\mathrm{COD}}\right), 2.19$ (nrm, $1 \mathrm{H}$, e-8- $\left.\mathrm{H}_{\mathrm{COD}}\right), 2.45\left(\mathrm{nrm}, 1 \mathrm{H}, \mathrm{a}-3-\mathrm{H}_{\mathrm{COD}}\right), 2.50$ (nrm, $1 \mathrm{H}$, a-7- $\left.\mathrm{H}_{\mathrm{COD}}\right), 2.69$ (nrm, $\left.1 \mathrm{H}, \mathrm{e}-3-\mathrm{H}_{\mathrm{COD}}\right), 2.79(\mathrm{nrm}, 1 \mathrm{H}$, e-7- $\mathrm{H}_{\mathrm{COD}}$ ), 3.51 (br s, NOE with 7.05 ppm, $1 \mathrm{H}, 5-\mathrm{H}_{\mathrm{COD}}$ ), 3.59 (br s, NOE with 7.05, 7.68 ppm, $1 \mathrm{H}, 6-\mathrm{H}_{\mathrm{COD}}$ ), 3.79 (br $\mathrm{d}, J=8.7 \mathrm{~Hz}, 1 \mathrm{H}, \mathrm{NCH}), 4.29\left(\mathrm{t}, J=9.4 \mathrm{~Hz}, 1 \mathrm{H}, \mathrm{OCH}_{2}\right)$, 4.33 (dd, $J=9.4 \mathrm{~Hz}, J=3.5 \mathrm{~Hz}, 1 \mathrm{H}, \mathrm{OCH}_{2}$ ), 5.27 (br s, $2 \mathrm{H}, 1-$ and 2- $\left.\mathrm{H}_{\mathrm{COD}}\right), 7.05$ (nrm, $\left.2 \mathrm{H}, 2^{\prime}-\mathrm{H}\right), 7.33$ (br dd, $J=$ $9.0 \mathrm{~Hz}, J=7.0 \mathrm{~Hz}, 1 \mathrm{H}, 3-\mathrm{H}), 7.41\left(\mathrm{t}, J=7.2 \mathrm{~Hz}, 2 \mathrm{H}, 3^{\prime}-\mathrm{H}\right)$, 7.50 (br s, $3 \mathrm{H}, 4^{\prime}-$ and $\left.3^{\prime \prime}-\mathrm{H}\right), 7.56$ (nrm, $\left.1 \mathrm{H}, 4^{\prime \prime}-\mathrm{H}\right), 7.61$ (nrm, $2 \mathrm{H}, 4$ - and 5-H), 7.68 (nrm, $\left.2 \mathrm{H}, 2^{\prime \prime}-\mathrm{H}\right), 8.09$ (m, $1 \mathrm{H}$, 6-H), and the signals of BARF. $-{ }^{13} \mathrm{C}\left\{{ }^{1} \mathrm{H}\right\} \mathrm{NMR}\left(\mathrm{CDCl}_{3}\right.$, $150 \mathrm{MHz}): \delta=12.29(\mathrm{Me}), 18.79(\mathrm{Me}), 26.33$ (8- $\left.\mathrm{CH}_{2 \mathrm{COD}}\right)$, $28.65\left(4-\mathrm{CH}_{2 \mathrm{COD}}\right), 30.70\left(3-\mathrm{CH}_{2 \mathrm{COD}}\right), 32.44\left(\mathrm{CHMe}_{2}\right)$, $35.33\left(7-\mathrm{CH}_{2 \mathrm{COD}}\right), 67.74\left(\mathrm{OCH}_{2}\right), 70.90(\mathrm{NCH}), 77.61(\mathrm{~d}$, $\left.J=11.5 \mathrm{~Hz}, 6-\mathrm{CH}_{\mathrm{COD}}\right), 79.05\left(\mathrm{~d}, J=12.6 \mathrm{~Hz}, 5-\mathrm{CH}_{\mathrm{COD}}\right)$, $105.52\left(\mathrm{dd}, J=11.5 \mathrm{~Hz}, J=8.0 \mathrm{~Hz}, 1-\mathrm{CH}_{\mathrm{COD}}\right), 107.66$ (dd, $\left.J=9.2 \mathrm{~Hz}, J=6.9 \mathrm{~Hz}, 2-\mathrm{CH}_{\mathrm{COD}}\right), 117.45$ (br s, $4^{\prime \prime}-\mathrm{CH}$ ), $124.33\left(\mathrm{~d}, J=49.3 \mathrm{~Hz}, 1^{\prime}-\mathrm{C}\right), 128.52$ (d, $\left.J=40.2 \mathrm{~Hz}, 2-\mathrm{C}\right)$, 128.54 (d, $J=14.9 \mathrm{~Hz}, 1-\mathrm{C}), 129.03$ (d, $\left.J=10.3 \mathrm{~Hz}, 3^{\prime}-\mathrm{CH}\right)$, 129.13 (1" -C), 129.80 (d, $\left.J=10.3 \mathrm{~Hz}, 3^{\prime \prime}-\mathrm{CH}\right), 131.81$ (d, $\left.J=2.3 \mathrm{~Hz}, 4^{\prime}-\mathrm{CH}\right), 132.20(\mathrm{~d}, J=2.3 \mathrm{~Hz}, 5-\mathrm{CH}), 132.64$ (d, $J=2.3 \mathrm{~Hz}, 4-\mathrm{CH}), 132.86\left(\mathrm{~d}, J=10.3 \mathrm{~Hz}, 2^{\prime}-\mathrm{CH}\right), 133.64$ (d, $J=8.0 \mathrm{~Hz}, 6-\mathrm{CH}), 133.72(\mathrm{~d}, J=13.8 \mathrm{~Hz}, 3-\mathrm{CH}), 134.46$ (d, $\left.J=12.6 \mathrm{~Hz}, 2^{\prime \prime}-\mathrm{CH}\right), 163.81(\mathrm{~d}, J=8.0 \mathrm{~Hz}, \mathrm{~N}=\mathrm{C})$, and the signals of BARF. $-{ }^{31} \mathrm{P}$ NMR $\left(\mathrm{CDCl}_{3}, 161 \mathrm{MHz}\right): \delta=$ $+30.7(\mathrm{~d}, J=154.1 \mathrm{~Hz})$. - HRMS ESI/FT-ICR: isotope cluster 584-586, found (calcd.): 584.1588, $100 \%$ (584.1590, $100 \%)$; 585.1596, $32 \%(585.1623,35 \%) ; 586.1613,5 \%$ (586.1657, 6\%).
cis-Bis-((4S)-2-(2-(diphenylphosphino)phenyl)-4-isopropyl4,5-dihydrooxazole)rhodium(I) tetrakis(3,5-bis(trifluoromethyl)phenyl)borate (6)

Synthesized from 2c (84 mg, $0.405 \mathrm{mmol})$, 1a (84 mg, $0.451 \mathrm{mmol}), n$-BuLi $(0.28 \mathrm{~mL}, 0.451 \mathrm{mmol})$, $[\mathrm{Rh}(\mathrm{COD}) \mathrm{Cl}]_{2}(40 \mathrm{mg}, 0.081 \mathrm{mmol})$, and NaBARF (144 mg, $0.162 \mathrm{mmol}$ ) according the general procedure A. After anion exchange the mixture was adsorbed on silica gel and the solvents evaporated. The column ( $20 \mathrm{~g}$ of silica gel) was packed with silica with the adsorbed complex placed on top. The column was first eluted with $c a .100 \mathrm{~mL}$ of hexane in order to remove cyclooctadiene, then with $\mathrm{CH}_{2} \mathrm{Cl}_{2}$. Yield: $81.6 \%$; brown crystals, unstable at r.t. even in crystalline form, should be stored at $-20{ }^{\circ} \mathrm{C} .-[\alpha]_{\mathrm{D}}^{21}=-687(c=0.115$, $\left.\mathrm{CHCl}_{3}\right) .-{ }^{1} \mathrm{H} \mathrm{NMR}\left(\mathrm{CDCl}_{3}, 600 \mathrm{MHz}\right.$, r. t. $): \delta=0.44$ (d, $J=6.8 \mathrm{~Hz}, 3 \mathrm{H}, \mathrm{Me}), 1.09$ (d, $J=6.8 \mathrm{~Hz}, 3 \mathrm{H}, \mathrm{Me}), 2.09$ $\left(\mathrm{m}, \mathrm{CHMe}\right.$ ), $3.85(\mathrm{~m}, 1 \mathrm{H}, \mathrm{NCH}), 4.39\left(\mathrm{~m}, 2 \mathrm{H}, \mathrm{OCH}_{2}\right)$, 6.87 (br s, 4 H, $2^{\prime}-$ and $\left.3{ }^{\prime} \mathrm{H}\right), 6.96$ (br m, $\left.1 \mathrm{H}, 3-\mathrm{H}\right), 7.12$ (t, $\left.J=7.5 \mathrm{~Hz}, 1 \mathrm{H}, 4^{\prime}-\mathrm{H}\right), 7.33\left(\mathrm{t}, J=7.5 \mathrm{~Hz}, 2 \mathrm{H}, 3^{\prime \prime}-\mathrm{H}\right)$, 7.42 (nrm, $\left.1 \mathrm{H}, 4^{\prime \prime}-\mathrm{H}\right), 7.45$ (nrm, $\left.1 \mathrm{H}, 4-\mathrm{H}\right), 7.49$ (nrm, $1 \mathrm{H}, 5-\mathrm{H}), 7.53$ (nrm, $\left.2 \mathrm{H}, 2^{\prime \prime}-\mathrm{H}\right), 7.96$ (br d, $J=7.5 \mathrm{~Hz}$, $6-\mathrm{H})$, and the signals of BARF. $-{ }^{13} \mathrm{C}\left\{{ }^{1} \mathrm{H}\right\}$ NMR $\left(\mathrm{CDCl}_{3}\right.$, $150 \mathrm{MHz}): \delta=16.06(\mathrm{Me}), 20.69(\mathrm{Me}), 32.46\left(C \mathrm{HMe}_{2}\right)$, $69.25\left(\mathrm{OCH}_{2}\right), 73.47(\mathrm{NCH}), 127.97$ (br s, $\left.3^{\prime}-\mathrm{CH}\right), 128.11$ (t, $J=6.9 \mathrm{~Hz}, 1-\mathrm{C}), 128.34\left(\mathrm{t}, J=4.6 \mathrm{~Hz}, 3^{\prime \prime}-\mathrm{CH}\right), 129.69$ $\left(4^{\prime}-\mathrm{CH}\right), 130.41(5-\mathrm{CH}), 130.76\left(\mathrm{t}, J=20.7 \mathrm{~Hz}, 1^{\prime \prime}-\mathrm{C}\right)$, 131.18 (4"-CH), 131.41 (br s, 6-CH), 132.52 (br s, 2'-CH), 132.71 (s, 3-CH), 132.92 (br s, 4-CH), 134.43 (dd, $J=$ $20.7 \mathrm{~Hz}, J=17.2 \mathrm{~Hz}, 2-\mathrm{C}), 134.72\left(\mathrm{t}, J=5.7 \mathrm{~Hz}, 2^{\prime \prime}-\mathrm{CH}\right)$, $163.63(\mathrm{~s}, \mathrm{~N}=\mathrm{C})$, and the signals of BARF, $1^{\prime}-\mathrm{C}$ is not identified, since the broad signal at $6.87 \mathrm{ppm}$ shows no cross peaks in an HMBC spectrum. - ${ }^{31} \mathrm{P} \mathrm{NMR}\left(\mathrm{CDCl}_{3}, 161 \mathrm{MHz}\right): \delta=$ $+49.3(\mathrm{~d}, J=174.8 \mathrm{~Hz})$. - HRMS ESI/FT-ICR: isotope cluster $849-852$, found (calcd.): $849.2263,100 \%$ (849.2246, $100 \%) ; 850.2285,49 \%(850.2280,52 \%) ; 851.2387,10 \%$ $(851.2313,13 \%)$.

\section{Acknowledgements}

V.S. thanks the Herbert-Quandt foundation and the German Academic Exchange Service (DAAD) for a doctoral fellowships and the partnership program between the University of Konstanz and the NTSU Kyiv for having the opportunity to perform his doctoral studies in Konstanz. We are grateful to Anke Friemel, Ulrich Haunz, Reinhold Weber and to Dmitry Galetskiy (University of Konstanz) for measuring of NMR and mass spectra, and to Milena Quentin for helping to prepare the manuscript, and to Umicore, MCAT, Bayer $\mathrm{AG}$, Merck $\mathrm{KGaA}$ and Wacker AG for generous gifts of reagents. 
[1] A. Lightfoot, P. Schnider, A. Pfaltz, Angew. Chem., Int. Ed., Engl. 1998, 37, 2897 -2899; Angew. Chem. 1998, $110,3047-3050$.

[2] P. Schnider, G. Koch, R. Pretot, G. Wang, F. M. Bohnen, C. Krüger, A. Pfaltz, Chem. Eur. J. 1997, 3, $887-892$.

[3] S. Kainz, A. Brinkmann, W. Leitner, A. Pfaltz, J. Am. Chem. Soc. 1999, 121, 6421-6429.

[4] M. Solinas, P. Wasserscheid, W. Leitner, A. Pfaltz, Chem. Ing. Tech. 2003, 75, 1153.

[5] V. Semeniuchenko, V. Khilya, U. Groth, Synlett 2009, $271-275$.

[6] A.M. Aguiar, H. J. Greenberg, K. E. Rubenstein, J. Org. Chem. 1963, 28, $2091-2093$.

[7] M. Peer, J. C. De Jong, M. Kiefer, T. Langer, H. Rieck, H. Schell, P. Sennhenn, J. Sprinz, H. Steinhagen, B. Wiese, G. Helmchen, Tetrahedron 1996, 52, 7547 7583.

[8] J. Sprinz, G. Helmchen, Tetrahedron Lett. 1993, 34, $1769-1772$.

[9] R. N. Constantine, N. Kim, R. C. Bunt, Org. Lett. 2003, $5,2279-2282$.

[10] J. V. Allen, G. J. Dawson, C. G. Frost, J. M. J. Williams, S. J. Coote, Tetrahedron 1994, 50, 799-808.

[11] K. Tani, D. C. Behenna, R. M. McFadden, B. M. Stoltz, Org. Lett. 2007, 9, 2529-2531.

[12] A. Frolander, S. Lutsenko, T. Privalov, C. Moberg, J. Org. Chem. 2005, 70, $9882-9891$.

[13] G. Koch, G. C. Lloyd-Jones, O. Loiseleur, A. Pfaltz, R. Pretot, S. Schaffner, P. Schnider, P. von Matt, Recl. Trav. Chim. Pays-Bas 1995, 114, 206-210.

[14] M. Zehnder, S. Schaffner, M. Neuburger, D. A. Plattner, Inorg. Chim. Acta 2002, 337, 287-298.

[15] D. G. Blackmond, A. Lightfoot, A. Pfaltz, T. Rosner, P. Schnider, N. Zimmermann, Chirality 2000, 12, 442 449.
[16] C. Y. Legault, A. B. Charette, J. Am. Chem. Soc. 2005, 127, 8966-8967.

[17] E. C. Ashby, R. Gurumurthy, R. W. Ridlehuber, J. Org. Chem. 1993, 58, $5832-5837$.

[18] N. V. Ushakov, V.M. Vdovin, M. V. Pozdnyakova, N. A. Pritula, Russ. Chem. Bull. 1983, 32, 1920-1923.

[19] A. Y. Garner, A. A. Tedeschi, J. Am. Chem. Soc. 1962, 84, 4734-4737.

[20] A. J. Kirby, S. G. Warren, The organic chemistry of phosphorus, Elsevier, Amsterdam 1967.

[21] J. A. S. Howell, N. Fey, J. D. Lovatt, P.C. Yates, P. McArdle, D. Cunningham, E. Sadeh, H. E. Gottlieb, Z. Goldschmidt, M. B. Hursthouse, M. E. Light, Dalton Trans. 1999, 3015-3028.

[22] R. H. Crabtree in The Handbook of Homogeneous Hydrogenation, Vol. 1 (Eds.: J. G. de Vries, C. J. Elsevier), Wiley-VCH, Weinhein 2007, chapter 2, pp. 31-44.

[23] R. H. Crabtree, H. Felkin, G. E. Morris, J. Organomet. Chem. 1977, 141, 205-215.

[24] D. L. Reger, C. A. Little, J. J. S. Lamba, K. J. Brown, J. R. Krumper, R. G. Bergman, M. Irwin, J. P. Fackler, Inorg. Synth. 2004, 34, 5-8.

[25] C. A. Busacca, J. C. Lorenz, N. Grinberg, N. Haddad, M. Hrapchak, B. Latli, H. Lee, P. Sabila, A. Saha, M. Sarvestani, S. Shen, R. Varsolona, X. Wei, C.H. Senanayake, Org. Lett. 2005, 7, 4277-4280.

[26] M. P. Cava, R. L. Litle, D. R. Napier, J. Am. Chem. Soc. 1958, 80, 2257-2263.

[27] A. Sudo, K. Saigo, Tetrahedron: Asymmetry 1996, 7, $2939-2956$.

[28] A. Sudo, K. Saigo, J. Org. Chem. 1997, 62, $5508-$ 5513.

[29] A. Frolander, S. Lutsenko, T. Privalov, C. Moberg, J. Org. Chem. 2005, 70, $9882-9891$. 